REVISTA DE DERECHO UNED, NÚM. 26, 2020

\title{
LAS GARANTÍAS CONSTITUCIONALES DEL PROCESO SIGUIENDO ENSEÑANZAS DE MI “MAESTRO” DR. D. JOSÉ ALMAGRO NOSETE
}

(IN MEMORIAM. SEVILLA 1934. CÓRDOBA 2019)

\author{
Juan Manuel Alonso Furelos \\ PROF. T.U. DERECHO PROCESAL \\ (UNIVERSIDAD NACIONAL DE EDUCACIÓN A DISTANCIA. U.N.E.D)
}

Resumen: Abordo en este trabajo en homenaje a mi maestro José Almagro Nosete recientemente fallecido las garantías constitucionales del proceso. Su origen y desenvolvimiento. Como inciden sobre la acción, la jurisdicción y el proceso. Y como se protegen.

Abordamos las mismas desde un plano cronológico y en los cuatro órdenes jurisdiccionales de la jurisdicción ordinaria. Hemos tenido en cuenta las enseñanzas del profesor Almagro Nosete, si bien es un trabajo "propio" y lo es al margen de todas las consideraciones que el homenajeado tuvo a bien destacar.

Palabras Clave: Garantías Procesales. Protección. Constitucionalización. Profesor Almagro Nosete.

Abstract: I address this work in honor to my maestro José Almagro Nosete recently deceased the constitutional guarantees of the process. Their origin and development. How they affect the action, jurisdiction and process. And how they protect themselves.

We address them from a chronological plane and in the four jurisdictional orders of the ordinary jurisdiction. We have taken into account the teachings of Professor Almagro Nosete, although it is a "proper" work and it is apart from all the considerations that the honoree had to highlight. 
Keywords. Procedural guarantees. Protection. Constitutionalization. Professor Almagro Nosete.

Sumario. I.- Palabras previas. II.- Orígenes del garantismo procesal. III.- Concepto y clases. IV.-Acción y jurisdicción en el garantismo procesal. V) El garantismo al servicio de la persona humana o justiciable. El sentido de la acción como libre acceso a la jurisdicción y al proceso y su relación con la legitimación. VI.- El proceso como método al servicio de las garantías procesales. VII.- La garantía procesal del libre acceso a la jurisdicción y al proceso. VIII.- Las garantías al servicio de la jurisdicción (art. 117 CE) lo están también al servicio del justiciable en cuanto forman parte también del derecho a la tutela judicial efectiva (art. $24 \mathrm{CE}$ ). IX.- Garantías respecto a la unidad y las formas del proceso y procedimiento. X) Garantías del principio de aportación según rija o no en el proceso el principio dispositivo. Relación con la acción, la fundamentación fáctica y jurídica, la causa petendi y la legitimación. Relación con el derecho de defensa y la congruencia. XI.- Garantías de la prueba. La independencia del Juez. XII.- Las garantías procesales en la conclusión del proceso. XIII.- Las garantías procesales de la sentencia XIV.-Garantías procesales de los recursos. Acceso a los mismos. Permisión o prohibición de la "reformatio in pejus". XV.- La garantía procesal de la cosa juzgada. XVI.-Las garantías procesales de la ejecución. XVII.La garantía del derecho de defensa en las medidas cautelares, en los juicios sumarios y en los plenarios rápidos. XVIII.- La garantía procesal de la responsabilidad judicial por dilaciones indebidas y errores judiciales. XIX.- La salvaguarda de las garantías procesales a través de los procesos especiales de impugnación. XX.- El principio de oportunidad frente al garantismo procesal. XXI.- Conclusión.

\section{PALABRAS PREVIAS.}

El día 17 de Agosto de 2019 nos dejó, como expresamente señala la esquela publicada en el periódico ABC de Córdoba del día 18 del mismo.

Fue el primer Catedrático de Derecho Procesal de la UNED tras su creación como Universidad en 1974. Hasta ese momento era Catedrático de Derecho Procesal de la Universidad de Salamanca (aunque estaba en servicios especiales), a la que había accedido por primera vez tras superar las oposiciones a la Cátedra en 1971. Antes había sido profesor Agregado de la Universidad Complutense de Madrid tras obtener la Agregaduría por oposición en 1969 y antes pro- 
fesor Adjunto en la Universidad de Sevilla, previo el paso inicial de Ayudante de Derecho procesal y Doctor en la misma.

Ocupó importantes puestos en la Administración del Estado.

Así el Ministerio de Educación y Ciencia no sé si como director general o subdirector general (comienzos de los años 1970).

Vocal, igualmente, de la Comisión de Codificación de Derecho Procesal del Ministerio de Justicia. En este mismo Ministerio de Justicia (desde 1987) fue Coordinador de los trabajos para la reforma del Derecho procesal civil (entiéndase reforma de la LEC de 1881 o para el establecimiento de una nueva LEC) nombrado por el Ministro de Justicia Enrique Múgica Herzog (cargo equivalente a Secretario de Estado); reforma que no concluyó en esa legislatura; y que en la posterior legislatura el Gobierno de Aznar creó una nueva Comisión para su reforma (de la que surgieron varios proyectos de Ley que culminaron el año 2000 con la vigente LEC).

Tras su paso por el mismo, accedió a Magistrado del Tribunal Supremo como jurista de reconocido prestigio por el cuarto turno.

En el ámbito de la empresa privada fue asesor jurídico del periódico YA prácticamente hasta el momento de su desaparición y destacó (además de por sus relevantes conocimientos jurídicos procesales en los que era una autoridad) por sus conocimientos penales, civiles, administrativos y constitucionales referidos al ámbito de la protección del derecho al honor, a la intimidad y a la propia imagen, de la libertad de expresión, prensa y difusión de los medios de comunicación, la prohibición de la censura previa y del secuestro administrativo previo de publicaciones. (Art. 16-1,18-1 y 3, 20-1-a y d-2,3,4 y 5, 53-2, 55 y 161-1-b todos de la CE)

En este trabajo dedicado a la memoria de mi "Maestro" José Almagro, no abordaré su ciclo vital (aspectos privados o públicos importantes o destacables desde su nacimiento a su deceso sean familiares, cargos académicos, públicos o privados, su significación política...). Tampoco sus principales obras.

La razón es que para abordar su ciclo vital necesitaría tener una información completa sobre la misma de la que carezco y el respeto que me mereció su derecho al honor, intimidad y propia imagen. Tampoco abordaré su obra evitando repeticiones innecesarias, pues con motivo del homenaje con ocasión de su jubilación en el Tribunal Supremo se imprimió un libro de "estudios" en su homenaje (El Tribunal Supremo, su doctrina legal y el recurso de casación: estudios en homenaje al profesor Almagro Nosete. Coordinado por José 
Vicente Gimeno Senda y María José Cabezudo Bajo. Madrid 2007. ISBN 978-84-96717-20-6. Páginas XV y ss.) donde el profesor Pablo Saavedra Gallo se ocupó de glosar su figura en dicho libro dentro del capítulo referido a su "laudatio" universitaria.

Asimismo, con motivo de su fallecimiento la Universidad del País Vasco le hizo un homenaje el día 25 de Noviembre del 2019 y al que se hace referencia en la Revista Vasca de Derecho Procesal y Arbitraje, Tomo XXXII, año 2020, Nº 1, páginas 147 a 166.

Finalmente, la fundación Dialnet tiene recogidas sus principales publicaciones en la "página web" a la que se puede acceder a través de cualquier buscador en internet (suelo hacerlo en "google" insertando los apellidos y nombre del homenajeado. Remitimos pues a las fuentes señaladas en los párrafos precedentes respecto al ciclo vital y su importante obra.

En este trabajo me limitó a abordar un tema recurrente de D. José cual es el garantismo procesal. Con él inició y desarrolló lo que consideramos es aspecto importante de su obra. Así quiso denominar a la Escuela por el fundada: "Escuela Garantista del Derecho Procesal". Podría ser la denominación de nuestra disciplina, es decir, derecho procesal, derecho jurisdiccional, derecho a la jurisdicción (o libre acceso de entenderse el derecho de acción según la teoría abstracta de la acción como un acceso libre e ilimitado), o el derecho de las garantías procesales (estén todas constitucionalizadas o no). He tomado como base las enseñanzas de D. José en las que se apreciará su gran influjo si bien se trata de un trabajo de "cosecha propia" por lo que ya puedo anticipar que ni tiene, ni pretende tener, la gran "altura de miras" que tuvieron las aportaciones impresas de mi "maestro". Sólo es un trabajo modesto, en homenaje a mi maestro que no busca otra "pretensión".

\section{ORÍGENES DEL GARANTISMO PROCESAL}

D. José, como acabo de señalar, tuvo especial predilección por el garantismo procesal de ahí el nombre con el que era conocida su "Escuela": la Escuela garantista del Derecho Procesal. Sus investigaciones, incluyo las anteriores a la CE de 1978 o las que dedicó a ella tras su vigencia, lo atestiguan con creces.

Con especial significación doctrinal sobre los orígenes del garantismo procesal, en Italia, merece destacarse a Pedro (Piero) Calamandrei y su discípulo Mauro Capeletti. Entiendo que no se puede 
incluir, como seguidores del garantismo procesal, como destacaremos, a la "Escuela social del derecho procesal italiano" cuyos máximos exponentes fueron Mortara y Lessona. Es discutible si pueden considerarse precedentes teniendo en cuenta la gran influencia que tuvo en Calamandrei Lessona y Mortara junto a Chiovenda.

En España, es Niceto Alcalá Zamora Castillo el primer procesalista que investigó la naturaleza y carácter del Tribunal de Garantías Constitucionales precedente del Tribunal Constitucional; más tarde Víctor Fairén Guillén (remito a lo expuesto en otras publicaciones sobre el seminario de Derecho procesal celebrado un día a la semana en el piso de N. Alcalá Zamora Castillo en la calle General Perón de Madrid tras fijar su residencia habitual en España tras su "exilio voluntario".

En Iberoamérica merecen destacarse el procesalista uruguayo, Eduardo J. Couture y el mejicano Héctor Fix Zamudio.

Por orden cronológico, para unos el primero es Couture y tras él Calamandrei (aunque se ocupó mucho del tema al final de sus días) y después Alcalá-Zamora Castillo. Para otros el primero es Calamandrei seguido de Couture y tras este Alcalá- Zamora.

Fuera del procesalismo científico, de las garantías procesales, y desde la perspectiva del Derecho político y del Derecho constitucional, en los años 20 del S. XX, merecen destacarse dos eminentes juristas que sostuvieron posiciones totalmente antagónicas y son Hans Kelsen (límites al poder del Estado) y Carl Schmitt (que mantiene su poder ilimitado del Estado sin contraposiciones externas).

Debe destacarse, que en los textos constitucionales españoles desde 1812, se preveían garantías procesales sobre todo para el proceso penal. Pero eran simples garantías formales, simples enunciados, sin una protección jurisdiccional directa o sustancial en caso de vulneración.

Así hasta que la Constitución Española de 1931 (art. 121) determinó el Órgano jurisdiccional encargado de dicha protección, conforme a la Constitución y sus garantías: el Tribunal de Garantías Constitucionales. Regido por la L.O. de 14 de junio de 1933 que estableció su régimen jurídico y procedimiento para su protección. Poco después comenzó a desplegar su actividad jurisdiccional dictando varias sentencias de gran relevancia referidas a los hoy denominados procesos de amparo y demás procesos constitucionales (por tanto, procesos no de simple relevancia constitucional como determina el 
vigente art. 53-2 CE, sino que lo sean al amparo del art. $161 \mathrm{CE}$ vigente).

Sin embargo, con anterioridad al garantismo procesal y cuyo centro está en el recurso de amparo procesal, hubo otra corriente procesal en Italia eminentemente social y que es coetánea a la Escuela mayoritaria italiana fundada por Chiovenda (Calamandrei, Redenti y Carnelutti). Toma también como base esencial a la persona humana, pero no desde una perspectiva individualista si no como partícipe del grupo social o Estado. Corriente procesal o "Escuela" doctrinal denominada social del proceso, que estudia y aborda la protección de los derechos procesales denominados "sociales".

Entre sus seguidores más relevantes merecen destacarse a los procesalistas Ludovico Mortara y a Carlo Lessona (este influyó en los trabajos iniciales de P. Calamandrei); los dos muy relacionados al ser discípulos de Luigi Mattirolo (aunque éste es considerado actualmente más un procedimentalista que un procesalista).

\section{CONCEPTO Y CLASES.}

El garantismo procesal debe ponerse en relación con los actos procesales realizados en el proceso por el Órgano jurisdiccional, el Letrado de la Administración de Justicia en cuanto tramitador procesal, las partes actoras y pasivas, o incluso que intervienen en los actos de prueba como testigos o peritos.

Deben tales actos practicarse conforme a las garantías procesales; actos y garantías procesales son en este sentido instrumentales al propio proceso. Sin perjuicio de qué siendo procesales dichos actos y las garantías procesales, al ser el proceso un instrumento para la aplicación del derecho material, dichas actos y garantías están no sólo en función del proceso si no de la aplicación del derecho material en el mismo al caso concreto. Y son un instrumento, a su vez, para la defensa jurídica de las partes en el proceso, de los justiciables, y en ese sentido sirven de medio dichos actos procesales y dichas garantías procesales para evitar que la indefensión se produzca. (Art. $24 \mathrm{CE}$ ). Dan seguridad a que la defensa jurídica en el plano formal y material sea la adecuada.

Siguiendo a Goldschmidt, si estas garantías procesales son la consecuencia de la realización de actos procesales de parte (o del órgano, del letrado de la administración de justicia o de terceros), a cuyo fin tienden, no serían propiamente un derecho o conjunto de 
derechos procesales; ni una obligación o conjunto de obligaciones procesales (sea desde el plano procesal o el constitucional del proceso). Tampoco serían propiamente facultades, ni derechos potestativos en sentido estricto.

Puede constituir el cumplimiento o práctica de dichas garantías una carga o un conjunto de cargas procesales en cuanto estén referidas a las partes y en este sentido sirven de medio instrumental para liberar esas cargas que una vez liberadas hacen nacer expectativas positivas o negativas para las partes, o simples posibilidades. Si es así desde el plano procesal, podría mantenerse esa afirmación desde el plano constitucional del proceso.

Pueden ser esas garantías una consecuencia de los principios que forman parte integrante del propio proceso o que son informativos de él (aportación, oralidad, publicidad, carga de la prueba o regla de juicio consecuencia de ella, actividad conclusiva en el proceso). Pueden ser también medios instrumentales para subsanar defectos o nulidades procesales. (Principio de subsanación, de saneamiento y de conservación de actuaciones procesales frente a la hipotética nulidad, anulabilidad insubsanable o radical e incluso inexistencia).

Si esas garantías se justifican en actos del juez o de su colaborador como el Letrado de la administración de justicia (ordenación procesal, prueba de oficio, diligencias finales ordenadas de oficio, sentencia judicial, saneamiento y subsanación de oficio de actos procesales, aclaración y complemento de la sentencia (Art. 214-215 LEC y concordantes de la LOPJ o leyes procesales atinentes a otros órdenes jurisdiccionales) son facultades o deberes reflejos del juez derivados del ejercicio de la potestad jurisdiccional o de la tramitación procesal del Letrado de la Administración de Justicia. (Art. 117 CE).

Toda garantía material proporciona una seguridad en el cumplimiento de los derechos y obligaciones jurídico-materiales de la persona. El aseguramiento material (personal o real) proporciona seguridad en el cumplimiento de los derechos y obligaciones y se consigue fuera del proceso con garantías materiales (fianzas o derechos reales de garantía) y en el proceso adoptando medidas cautelares. La seguridad procesal en el cumplimiento de las formas y garantías de los actos procesales de parte (cargas, su liberación, posibilidades, expectativas positivas o negativas) aumenta positivamente con las garantías procesales en aras de la defensa jurídica sobre todo si están constitucionalizadas. Igual sucede con los actos del juez o del "tramitador procesal". 
Seguridad siempre concatenada con la adecuada defensa jurídica, medio e instrumento que sirve a las partes para alcanzar la tutela judicial efectiva (Art. $24 \mathrm{CE}$ ). Pero a su vez, con esa seguridad procesal que proporcionan estas garantías al proceso, se evita o impide que pueda producirse la indefensión de ambos justiciables o de uno de ellos (Art. $24 \mathrm{CE}$ ).

Lo cierto es que estas garantías procesales han sido asumidas como tales por el legislador en los Estados con un sistema democrático y constitucional. Y como tales garantizan que el proceso llegue a buen fin, estén esas garantías dotadas de una protección simple o reforzada, es decir, buscan una solución justa al proceso en consecuencia con el derecho de defensa que corresponde a las partes (art. 24).

Y garantizan que, en ningún caso lógicamente, desde el marco procesal legal establecido se pueda justificar la indefensión (art.24). Así la certeza y seguridad jurídica justifican la cosa juzgada pero el fraude procesal y la falta de garantías procesales justifican la revisión de la propia cosa juzgada. Fuera de lo dicho, estas garantías procesales, deberían estar asumidas por toda opción política si afirmados el carácter apolítico del Derecho procesal. Si se optara por el carácter político del Derecho procesal, y se justifica su politización, estarían más que justificadas en las opciones democráticas.

Clases. Las hay que estando constitucionalizadas además son objeto de una protección jurisdiccional reforzada ante el Tribunal Constitucional mediante el recurso de amparo (las previstas en el art.24 CE), una vez agotada la vía jurisdiccional ordinaria.

Otras son garantías establecidas (o asumidas) por el Tribunal Europeo de Derechos Humanos TEDH (así la doble instancia penal para los delitos graves, donde antes de la última reforma penal sólo se admitía el recurso de casación para estos y sin embargo sí la apelación para los menos graves) y en este sentido nos vinculan por el Tratado de adhesión a Europa con sus Convenios o son consecuencia de Acuerdos internacionales suscritos por España (art. $10 \mathrm{CE}$ y art. 3 y 4 LEC) con otro país o con Organizaciones Internacionales. Vinculan directamente al legislador español esas garantías y serán tomadas como base respecto a las futuras reformas legislativas; o la futura jurisprudencia de nuestros Tribunales, y algunas son susceptibles de ser exigidas directamente ante el TEDH para que garantice su cumplimiento a posteriori en el nuevo proceso revisorio que deba seguirse en España.

Otras garantías procesales no tienen esta protección reforzada, pero pueden reclamarse ante los Tribunales mediante los recursos 
ordinarios (apelación), o los extraordinarios de infracción procesal o incluso a través del incidente de nulidad de actuaciones conforme a lo previsto en nuestras leyes procesales.

Unas son comunes a todo proceso jurisdiccional (civil, laboral, penal y contencioso administrativo) en su orden jurisdiccional respectivo. Otras son específicas del proceso penal y de este orden jurisdiccional. También según el momento del proceso al que se refieren pueden tener relevancia en el momento inicial de éste en cuanto sirven de medio de acceso al proceso y a la propia jurisdicción; o son una vez iniciado una consecuencia del principio de aportación, del principio de contradicción en la práctica de la prueba, de la sentencia, del acceso a los recursos ordinarios o extraordinarios o referidos a su trámite, o consecuencia de la cosa juzgada (o de la cosa ejecutada) de las sentencias.

Son titulares de dichas garantías procesales las partes, por el simple hecho de serlo; y su destinario es el órgano jurisdiccional o el tramitador procesal al que vinculan y por ello debe respetarlas y protegerlas, adoptándolas a instancia de parte o de oficio.

El proceso es el instrumento para actuar el derecho material al caso concreto. Las garantías procesales son un instrumento del proceso; pero lo son también para que se aplique la norma material de forma justa. Refuerzan así la calidad "moral o ética" del proceso y "su" justicia. Están sobre todo al servicio de las partes, de ambas, garantizando importantes principios como el de contradicción, igualdad formal y su derecho constitucional a la defensa jurídica en cuanto queda proscrita la indefensión.

\section{ACCIÓN Y JURISDICCIÓN EN EL GARANTISMO PROCESAL.}

El garantismo procesal fue, en su día, una reacción a una concepción del Derecho procesal fundada en un jurisdiccionalismo extremo y al servicio del Estado. Su fundador y la posición inicial más extrema en lo doctrina se justificó por Carl Schmitt.

Según esta posición doctrinal la esencia del Derecho procesal es la jurisdicción y la potestad jurisdiccional consistente en interpretar y aplicar el Derecho al caso concreto debe hacerse conforme al designio, el fin y el interés del Estado, incluso al margen de la propia norma procesal o material. No se olvide que la jurisdicción es uno de los tres trípodes sobre los que se asienta el Derecho Procesal y según las teorías jurisdiccionalistas la jurisdicción tendría un pa- 
pel prevalente y destacado sobre los otros dos trípodes: la acción y el proceso.

Es decir, según esta corriente, la jurisdicción prevalece sobre la acción (sobre el poder de las partes procesales -la actora o pasiva- de reclamar al Estado una tutela jurisdiccional -es decir, una sentencia de fondo- justa de contenido concreto o abstracto); y ese poder está desligado del derecho material aducido; comprende el poder o la facultad de la parte de deducir el objeto del proceso (sea el de la parte actora- la pretensión-; o el de la pasiva -cuando deduce otra pretensión reconviniendo o una excepción material de fondo que deje sin efecto jurídico la pretensión del actor con base a hechos impeditivos, extintivos o excluyentes).

Ese poder de la acción procesal, prima facie, sin embargo, implica conceder legitimación procesal (al margen de la legitimación material que se tiene por intervenir en la relación de derecho privado) a efectos procesales a cada parte para reclamar a través de la acción ese objeto a lo largo del proceso con base en los hipotéticos derechos subjetivos materiales aducidos o los intereses legítimos reclamados si son dignos de protección jurídica y sobre el proceso. Acción procesal que (según sea más abstracta o más concreta) delimita la legitimación procesal en términos más abstractos y genéricos, o más concretos y específicos. Si la acción procesal en esencia es inmutable (poder dirigido frente al Estado a través de los órganos jurisdiccionales) por el contrario la legitimación según la doctrina legal del TS (art. 1 y 3 CC) tiene carácter mutable en un cuerpo social cambiante.

El jurisdiccionalismo tuvo gran predicamento en Italia, sobre todo desde la concepción Carneluttiana y que fue concretada y desarrollada por sus discípulos más destacados. Merece destacarse a Enrico Allorio.

El garantismo procesal viene a ser una reacción procesal a los excesos cometidos por los regímenes totalitarios en la época de entreguerras (fascistas y comunistas) que justifican (Karl Smith) una concepción exclusivista y autoritaria de la jurisdicción puesta al servicio del Estado (fascista o comunista), más que al servicio del individuo en cuanto persona humana.

Según esta concepción el órgano jurisdiccional debe poner siempre la jurisdicción o su potestad jurisdiccional al servicio del Estado "nacional" o "popular socialista"; y como servidor del Estado y de la propia comunidad que lo encarna tiene el deber de interpretar las leyes y aplicarlas conforme a ese designio o interés del Estado 
y al margen de toda independencia judicial. Interés del Estado, que como destaca Carl Schmitt, es siempre superior al de la persona humana y al de la propia jurisdicción o juez que la desempeña.

Este autor influyó en cierta medida en el Derecho procesal de España al comienzo de la postguerra entre 1939 a 1945. Así en el profesor de Derecho político Conde que tradujo la obra de Carl Schmitt; en el procesalista Miguel Fenech (en su obra "La posición del juez en el nuevo Estado") y en menor medida en Jaime Guasp, (véase su obra "Juez y hechos en el proceso civil"). Muchos excesos judiciales cometidos al amparo de esta concepción en dicho periodo se justificaron sobre la base del exclusivismo jurisdiccional.

Por supuesto y sin ánimo de que se me malinterprete, el jurisdiccionalismo concebido y estudiado fuera de esta justificación y exceso al que refiero en párrafos anteriores es perfectamente defendible dentro de un Estado de Derecho, séalo social o liberal; que forma parte de los textos legislativos y constitucionales junto con las garantías procesales propias de la jurisdicción y de la acción (persona humana) puestas al servicio y defensa de todo tipo de derechos materiales e intereses legítimos susceptibles de protección jurídica, incluidos sobremanera los derechos fundamentales de la persona.

Aunque no es lo mismo, como el lector podrá comprender, dar prevalencia a la jurisdicción sobre la acción, a la acción sobre la jurisdicción que mantener a ambas acción y jurisdicción en una posición de correlación, igualdad y equilibrio. Así parece que la jurisdicción debería estar siempre al servicio de la acción.

Y las garantías de la jurisdicción constitucionalizadas (así las del art. $117 \mathrm{CE}$ ) o las no constitucionalizadas (que están en la LOPJ y Ley de Enjuiciamiento civil u otras leyes procesales) deben estar al servicio de la acción, en cuanto son medio e instrumento de la acción y de la jurisdicción. Su fin es siempre la consecución de la tutela judicial efectiva (art. $24 \mathrm{CE}$ ) y lo están al servicio de ambas partes del proceso la activa o la pasiva. La jurisdicción (art. $117 \mathrm{CE}$ ) desligada de la acción (art. $24 \mathrm{CE}$ ) y el correlativo derecho de defensa de los propios justiciables, parece que no tendría mucho sentido si no es para justificar un Estado autoritario.

Una jurisdicción sobrevalorada, prevalente, que esté al margen de la acción entendida como libre acceso a la jurisdicción (desligada de la legitimación) y sin la protección de las garantías constitucionales del proceso que están tanto al servicio de la acción como de la jurisdicción sería otra cosa, sin ningún género de duda. 
Incluso con el simple recurso de apelación para subsanar defectos de forma cuando se han vulnerado las garantías procesales (entendida la apelación como simple recurso de impugnación a los meros efectos procesales de anular y dejar sin efecto los vicios procesales cometidos y no como la doble instancia en caso de aplicación indebida de la norma material); con el de casación por quebrantamiento de las formas esenciales del juicio es decir las garantías procesales en los órdenes jurisdiccionales en que se prevé o con el actual recurso en lo civil de infracción procesal a este objeto; o con el incidente de nulidad de actuaciones, pero sin la admisión del recurso de amparo constitucional (art. $24 \mathrm{CE}$ ) como sucedía en las LEC de 1855 y 1881, la situación sería muy diferente.

\section{EL GARANTISMO AL SERVICIO DE LA PERSONA HUMANA O JUSTICIABLE. EL SENTIDO DE LA ACCIÓN COMO LIBRE ACCESO A LA JURISDICCIÓN Y AL PROCESO Y SU RELACIÓN CON LA LEGITIMACIÓN.}

La acción entendida como libre acceso a la jurisdicción y el propio garantismo procesal se centran y toman como base la persona humana. Por tanto, tienen una vertiente humanista que no puede negarse.

Persona humana que como titular de derechos subjetivos y de intereses jurídicos dignos de protección, ante su incumplimiento, se ve obligada a reclamarlos a través del proceso, y en su virtud, para su defensa, se le otorga a priori legitimación procesal. Acción que resulta previa a la legitimación procesal a la que está concatenada, aunque la legitimación material sea previa al proceso y forme parte de la cuestión de fondo en cuanto los sujetos del proceso en su momento intervinieron en la relación jurídica material (v.gr. contrato). Se ajusta esta concepción a una visión democrática del Derecho sobre todo cuando se constitucionalizan las garantías del proceso (art. $24 \mathrm{CE}$ ). Esto sin perjuicio del marcado carácter apolítico que debe presidir la jurisdicción, la acción y el proceso. Si esto parece cierto, al menos en teoría, en la práctica esta afirmación puede ser objeto de muchas aristas, dependiendo del momento concreto, sobre todo en el caso del proceso penal y del proceso contencioso administrativo. Esto al margen de la judicialización de la política o la politización de la justicia. 
La legitimación material, como regla general, es una cuestión de fondo previa al proceso, a decidir en la sentencia, y por lo tanto debería quedar al margen del proceso.

Pero no es menos cierto, que el simple hecho de aducir los derechos subjetivos materiales o los intereses legítimos como propios y la necesidad de fundamentarlos fáctica y jurídicamente para su concreción, tal cual exige la vigente LEC, determina (o justifica) al menos "prima facie" que dicha legitimación procesal esté fundamentada fáctica y jurídicamente (para que sea verosímil o aparente la legitimación material es decir, la titularidad del derecho material o del interés legítimo; o el "contra derecho" material que justifica la excepción material de fondo o el interés legítimo en que se ampara tal contraderecho digno de ser tutelado). Por tanto, apariencia o verosimilitud de legitimación material y por ello que cualquiera de las partes (actora o pasiva) actúan en el proceso como partes legitimadas a los meros efectos procesales.

Si se desligara totalmente la legitimación material como cuestión de fondo, de la legitimación procesal o poder de actuar (acción procesal) en juicio en nombre propio no sería fácil dar respuesta a ciertas figuras procesales como la existencia o inexistencia del litisconsorcio pasivo necesario antes de la sentencia sobre el fondo. Y su existencia, caso de incumplimiento de sus garantías procesales haría nula la sentencia por indefensión.

No se olvide tampoco que el derecho a la defensa jurídica de la parte (art. $24 \mathrm{CE}$ ) se concreta, aunque solo en parte, con la legitimación. Se lleva a cabo, normalmente a través del abogado cuando se exige la defensa técnica y es formal y material; y esta legitimación en cuanto concreta el objeto del proceso determina la adecuación de la defensa técnica o la incorrección de la defensa técnica. Y si se ejercita dentro de las garantías procesales determinará la inimpugnabilidad de la sentencia que se dicte si se ajusta a la forma, pero concretará, según el caso, la posible responsabilidad civil letrada o si faltaron justificará su impugnabilidad excluyéndose esa responsabilidad civil letrada.

Lo mismo debe decirse en el ámbito (por esta legitimación y objeto) de la representación que asume el procurador, para que dentro de esta representación técnica sea correcta o incorrecta y se pueda considerar adecuada o no su representación y que se manifiesta, (aunque no siempre es así) en la corrección de los actos de comunicación del procurador con el abogado y la parte. 
Toma entonces un papel sobresaliente la acción procesal que es el medio o instrumento con el que la persona humana (o la persona jurídica) accede a la jurisdicción y al proceso de forma libre. De ahí el nombre utilizado respecto a la acción en una de las primeras publicaciones del profesor Almagro como "libre acceso a la jurisdicción". Y es un poder que tiene la parte frente al Estado, exigiendo un derecho de prestación a una resolución justa fundada en derecho, el derecho a la jurisdicción, y además es una garantía procesal de la parte consecuencia de la acción, para que el acceso a la jurisdicción sea total y pleno por el mero hecho de aducir en abstracto derechos o intereses legítimos como propios.

Es decir, ese acceso al proceso (litispendencia, art. 410 LEC), es previo a la jurisdicción; es previo a la fundamentación fáctica y jurídica de la demanda (con la que se hace valer la pretensión); previo a la contestación a la demanda (con la que se hace valer la excepción material de fondo), según los parámetros exigidos por el Derecho para que se considere ejercido; y a que se tenga prima facie por existente o concurrente la legitimación procesal por el simple hecho de aducir como propios tales derechos o intereses legítimos.

A medida que la acción se conciba de una forma más abstracta (teoría abstracta de la acción procesal, inicialmente defendida por Teodor Muther) y menos requisitos se exijan para la legitimación procesal más garantista será el acceso a la jurisdicción.

A medida que se exija una mayor concreción en la tutela jurídica solicitada o teoría concreta de la acción procesal (propugnada por Savigny y después Windscheid, Wach, Khöler, Helwig, Chiovenda) mediante la adecuada fundamentación fáctica y jurídica de la demanda o de la contestación a la demanda (caso de proponerse una excepción material de fondo a la pretensión con base a hechos impeditivos, extintivos o excluyentes que la dejen sin efecto, véase en este sentido a Morón Palomino) más difícil resultará ese acceso para una u otra parte, en tanto en cuanto tenga que concretarse la acción o la tutela jurídica solicitada mediante la fundamentación de la pretensión o de la excepción de fondo y de la propia legitimación procesal.

Y todavía más difícil será el acceso si se exige, como prueba prima facie de esa apariencia de legitimación procesal y material, acompañar unos documentos tasados con la demanda o con la contestación a la demanda como requisito "sine que non" para la admisión a trámite de la demanda o para que se tenga por "bien propuesta" la excepción material en la contestación. Algunos autores, se refieren a esta exigencia (prueba "prima facie" de la legitimación 
procesal aportando documentos tasados con la demanda para su admisión a trámite o para que se tenga por bien formulada la excepción material) denominándola poder de "conducción procesal", quizá a consecuencia de una "atrevida" traducción literal del término alemán que lo contiene. Pues bien, esta exigencia es una limitación o un impedimento al derecho de acción, siempre entendida como libre acceso a la jurisdicción.

Este acceso debe ser en igualdad de condiciones tanto para la parte actora como para la pasiva. Ambas partes, en dualidad de posiciones, bajo el principio de contradicción, deben actuar con semejantes medios de ataque y defensa, en igualdad de condiciones, al menos formalmente para que sea posible su defensa jurídica 8art. $24 \mathrm{CE}$ ). Garantía procesal consustancial a la acción, es la igualdad de medios de ataque y defensa para evitar la indefensión o con otras palabras garantizar la proscripción de la indefensión.

Este libre acceso de las partes lo es para la primera instancia, la segunda o recurso de apelación, o para los recursos extraordinarios permitidos (infracción procesal y casación). Incluso para los procesos de impugnación autónomos y extraordinarios de sentencias judiciales firmes (audiencia al rebelde, revisión, incidente de nulidad de actuaciones, amparo...). Y guarda así este derecho de acceso a la jurisdicción, un gran paralelismo con el derecho de defensa y con la proscripción de la indefensión en tanto en cuanto no esté justificada. Son diversos planos del derecho de acción procesal y del garantismo procesal.

Se construya la acción como el motor inicial del proceso (acceso a la jurisdicción), como un motor continuo o como el motor final del proceso lo es del derecho de los justiciables a la jurisdicción, (art. 24 $\mathrm{CE}$ ) y del derecho deber que supone la potestad jurisdiccional (art. $117 \mathrm{CE}$ ) a la que se ha accedido antes y no puede negarse que afecta en todo caso al acceso y prosecución de la jurisdicción.

Pero afecta también a la fundamentación fáctica y jurídica de la demanda y a la contestación de la demanda (si se plantea una excepción de fondo a la pretensión basada en hechos impeditivos, extintivos o excluyentes); al principio de aportación; a la prueba contradictoria y sus garantías procesales en cuanto referidas al derecho de defensa y en especial a la carga de la prueba; a la conclusión oral o escrita del proceso; a las diligencias finales; a la motivación y fundamentación de la sentencia; al recurso de apelación se trate de una segunda instancia o una simple impugnación procesal; a los recursos extraordinarios; a la cosa juzgada; a la ejecución de la sentencia en 
los términos establecidos por la sentencia firme (ejecución común o "cosa" ejecutada) o la sentencia todavía no firme (ejecución provisional).

Y todo ello es común al proceso civil, laboral, penal y contencioso administrativo (sin perjuicio de sus respectivas especialidades) aunque los términos procesales usados en párrafos precedentes se sustituyan por otros en especial para el proceso penal.

\section{EL PROCESO COMO MÉTODO AL SERVICIO DE LAS GARANTÍAS PROCESALES.}

El proceso, tercer elemento esencial sobre el que descansa nuestra disciplina junto a la acción y la jurisdicción es para D. José un método. Dentro del método incluye la vertiente externa del proceso (procedimiento) y la interna del proceso (presupuestos y requisitos).

D. José sigue así una posición muy original, al considerar el proceso un método.

Se aleja de otras concepciones que lo concibieron como una relación jurídica subjetiva (sea unilateral entre el juez y las partes; bilateral entre el juez y las partes y las partes y el juez; o triangular entre el juez y las partes, las partes y el juez y las partes entre sí) con un objeto; o como una relación jurídica compleja, tratando de salvar la crítica de Goldschmidt del párrafo siguiente.

O como una situación jurídica compleja, dinámica y variable (J. Goldschmidt) al negar este autor que de los actos procesales realizados por las partes en el proceso puedan surgir derechos y obligaciones sinalagmáticos entre sí como sucede en la típica relación jurídica de derecho privado. No existen en el proceso derechos y obligaciones procesales y mucho menos sinalagmáticos entre sí (que el derecho procesal de una parte constituya la obligación de la contraparte y viceversa, como sucede en el ámbito del derecho privado contractual donde el derecho de un contratante se relaciona con la obligación del otro). En el proceso existen por el contrario cargas procesales -de cuya liberación o no- surgen expectativas procesales positivas o negativas y posibilidades.

O como una institución jurídica según la concepción de J Guasp.

Método que en la concepción procesal de D. José tiene que respetar las garantías procesales. A su vez los presupuestos procesales son garantías procesales del método para que se pueda tramitar un pro- 
ceso válidamente hasta el final y terminar con una sentencia de fondo. Ya se refieran al órgano jurisdiccional (jurisdicción, orden jurisdiccional, competencia). A las partes (legitimación procesal, litisconsorcio pasivo necesario, defensa letrada y representación por procurador). $\mathrm{O}$ al objeto concreto y determinado (su falta puede ser un defecto sustancial en la redacción de la demanda o contestación) e impedir la litispendencia o la cosa juzgada de un proceso anterior). La falta de un presupuesto procesal conlleva un impedimento procesal.

$\mathrm{O}$ respetar las condiciones positivas o negativas de procedibilidad cuyo incumplimiento origina óbices de procedibilidad positivos o negativos que muchas veces suponen el incumplimiento de garantías procesales, aunque no siempre.

Pasemos pues a concretar, enumerando, las garantías procesales y lo hacemos de forma cronológica. Frente a estas garantías existen límites o impedimentos que las excluyen. Enunciaremos las más importantes en forma general, salvo si son específicas de un determinado proceso sea el civil, laboral, penal o contencioso administrativo.

\section{LA GARANTÍA PROCESAL DEL LIBRE ACCESO A LA JURISDICCIÓN Y AL PROCESO.}

Como señalé se trata de una garantía procesal de la acción entendida como libre acceso a la jurisdicción y al proceso en favor del justiciable. Cuanto más fácil sea el acceso y menos los requisitos exigidos mayor será su amplitud. Por el contrario, a medida que se exijan más requisitos, más difícil y complejo será este, es decir, se limitara dicho acceso. Hasta el punto qué, si tales requisitos fueran desmesurados, se impediría dicho acceso.

Cuanto más abstracta sea la acción, más fácil resulta el acceso a la jurisdicción y al proceso. Menos o menores serán los requisitos exigidos para concretar la acción y la fundamentación de la pretensión o de la excepción, es decir para su ejercicio. A medida que se tenga que concretar la acción con actos previos, o la pretensión o la excepción con una concreta fundamentación fáctica o jurídica (aunque su falta total podría considerarse incluso defecto en la forma de presentación de la demanda o de la contestación a la misma); o si se exige la presentación de documentos específicos para la admisión a trámite de la demanda (litispendencia) que demuestren "prima facie" la legitimación de la pretensión del actor o para que se tenga por bien propuesta la excepción de fondo del demandado más se 
está limitando el ejercicio del derecho de acción entendido como libre acceso a la jurisdicción y al proceso del actor o demandado.

También se limita dicho acceso, retrasando temporalmente el ejercicio de la acción del actor cuando se le exige previamente la realización de ciertos actos previos al proceso sea civil, laboral, penal o contencioso administrativo.

1) Así en el proceso laboral cuando se exige el intento de una conciliación previa que finalizó sin acuerdo para admitir a trámite la demanda laboral. Se hace obligatorio el intento de conciliación previa y que finalice sin acuerdo (no es, pues, voluntaria), pues el acuerdo evita el proceso laboral. Así sucede con la conciliación laboral. Si se llega a acuerdo en dicho acto autocompositivo ya no es necesario el proceso pues dicho acuerdo sustituye a la sentencia del proceso e impide el propio proceso (excepción procesal de fondo o material). Sólo la falta de acuerdo del acto de conciliación permite el proceso.

2) En el proceso civil. La conciliación civil hasta la reforma de 1984 (de la LEC de 1881), era obligatoria. Desde esta fecha, como en la vigente LEC 2000, pasa a ser voluntaria. Existe sin embargo una diatriba doctrinal: un sector doctrinal propugna la vuelta a la obligatoriedad de la conciliación con ciertos requisitos y otro sector prefiere que en vez de la conciliación previa se justifique que existió un intento de mediación exclusivamente privado. Otro sector considera que debe seguir siendo voluntaria, como en la vigente Ley reguladora de la Jurisdicción voluntaria.

También se propugna el arbitraje sea voluntario o incluso forzoso, como medio para descongestionar la justicia civil. Es otra vía que al margen de que suponga, o no, un límite al libre acceso a la jurisdicción se justifica para descongestionar la jurisdicción. Es admisible en el orden jurisdiccional civil y laboral. Incluso para casos especiales en el Derecho Administrativo.

3) En el proceso penal. Se exige la conciliación previa en los delitos privados de injuria y calumnia entre particulares. Las injurias y calumnias a funcionarios son delitos públicos y no admiten la conciliación previa. Igualmente, en el proceso penal para proceder contra jueces y magistrados por delitos cometidos en el ejercicio de su cargo se exige una actividad procesal previa para su comprobación. También en los delitos cometidos por Diputados y Senadores nacionales, en el ejercicio de su función parlamentaria, se exige la previa autorización de su Cámara para iniciar el proceso penal. Se discute si este privilegio se extiende a los Diputados Autonómicos de pre- 
verlo su Estatuto Autonómico. De no preverse no se admite tal privilegio y sería preciso su reforma para la inclusión. Es discutible, de incluirse, su constitucionalidad o no con base en el art. 149-I- $6^{\circ} \mathrm{CE}$ por ser la legislación procesal una competencia exclusiva del Estado.

La jurisprudencia ha limitado también el ejercicio de la acción popular a la que se refiere el art.125 CE y 101 y ss. LECRIM, a algunos delitos sujetos a perseguibilidad pública. Con base en la legitimación que justifica la acción popular, sentó el TS como doctrina legal que debe existir un interés específico en el actor popular para ejercitar la acción popular y el derecho de acusación en el proceso penal, es decir, haber sufrido el que ejercita la acción popular un perjuicio que sin ser directo sea al menos reflejo y suficiente para considerarse ofendido o perjudicado penalmente en un particular delito. (Caso Banco Santander). Ello sin perjuicio del ejercicio de la acción civil derivada del delito ya ante la jurisdicción penal o la civil según procediese y por quién tuviera legitimación para ello.

Por el contrario, se amplió el libre acceso a la acción popular en el caso de los delitos que antes exigían la previa denuncia del ofendido, pues en muchos de ellos -tras el vigente Código Penal-, desapareció el requisito de la denuncia previa del ofendido para poder constituirse como parte actora el Ministerio Fiscal. Y así se convirtieron en delitos sujetos a procedibilidad pública que admiten la acción popular, sobre todo por las asociaciones defensoras de la mujer que la ejercitan, en el caso de los delitos contra la libertad sexual.

Igualmente, en los países en que el ejercicio de la acción penal corresponde al Ministerio Fiscal en exclusiva de éste, y se excluye la acción popular siendo un "impedimento" al derecho de acción como libre acceso al proceso penal.

Si, además, por el juego del principio de oportunidad se permite al Ministerio Fiscal en ciertos delitos no ejercitar la acción penal, con base a dicha oportunidad si se permite su total discrecionalidad para ello vemos que el impedimento al libre acceso a la jurisdicción puede ser total. Queda claro que en ese sistema no cabe el ejercicio de la acción penal popular, al ser la acción penal exclusiva del Ministerio Fiscal o de éste y el agraviado, perjudicado o víctima dependiendo de los sistemas del derecho comparado continental.

Considero que el libre acceso a la jurisdicción y al proceso penal que supone el ejercicio de la acción penal debe en todo caso ser una garantía procesal para la víctima del delito. Resulta así de las nuevas líneas del proceso penal justificadoras de la legitimación de la víc- 
tima o de asociaciones que asumen su libre defensa de forma desinteresada.

Se podrían incluir las inmunidades personales, en cuanto límite que impide el ejercicio o la prosecución de la acción penal en cuanto es una excepción personal procesal y material a la pena, art. 666-1 LECRIM y hace innecesario la prosecución del proceso penal, impidiendo abrir el juicio oral e incluso poniendo fin al sumario desde que se conoce que existe dicha inmunidad personal en un sujeto. Así en favor del cuerpo diplomático, de los Jefes de Estado extranjeros, $\mathrm{u}$ otras personas asimiladas con dicha inmunidad por Tratado Internacional sea bilateral o multilateral.

4) En el proceso contencioso administrativo.

- Puede incluirse como límite al libre acceso la necesidad de agotar el administrado previamente la vía administrativa ante la Administración. Es la regla general para el administrado. Es decir, no puede acudir el administrado al proceso contencioso administrativo reclamando algo a la Administración, directamente, si antes no agotó la vía administrativa. La excepción se produce cuando se trata de dos Administraciones públicas diferentes, en cuyo caso pueden acudir directamente al proceso contencioso administrativo, sin que quepa agotar previamente la vía administrativa. Si se trata de dos órganos de la misma Administración no se puede olvidar el principio de jerarquía y subordinación administrativa que de hecho impiden toda vía administrativa previa y el acceso a la jurisdicción contenciosa administrativa.

- Otro límite al acceso al proceso, es la necesaria reclamación administrativa previa del Administrado futuro demandante, agotada la vía administrativa previa del párrafo anterior, en los casos en que así se establezca por ley o reglamentariamente, antes de acudir al proceso contencioso administrativo. En ocasiones, su fin, es el de una conciliación encubierta, donde la falta de acuerdo entre Administrado y Administración permite iniciar el proceso administrativo y el acuerdo entre ambos lo evita. En la mayor parte de los casos, la Administración, ante esa reclamación administrativa previa, se limita a "actuar pasivamente" bajo la figura del silencio administrativo negativo.

- El requisito previo de que el administrado -futuro demandante- agotada la vía administrativa publique por edictos en periódicos oficiales o se inserte en el tablón de anuncios del 
Ayuntamiento (asuntos referidos a la Administración local) la resolución administrativa objeto de impugnación en el proceso administrativo si el contenido de la sentencia dictada en el procedimiento administrativo pudiera afectar a terceras personas y a los meros efectos de que ejerciten su derecho de defensa (art. $24 \mathrm{CE}$ ) por si estos terceros desearan constituirse en parte pasiva coadyuvando con la Administración (en cuanto están legitimados coadyuvando en favor de la Administración oponiéndose a la pretensión del administrado demandante). Más discutible es su admisibilidad en el plano activo, pues parece que en vía administrativa deberían haber intervenido mostrándose parte. Es pues un límite añadido en este caso a dicho acceso jurisdiccional.

- En supuestos específicos puede establecerse la necesidad de una conciliación previa que sustituya a la reclamación administrativa previa.

5) Límite al acceso, de carácter general, común a todo proceso civil, social, penal y contencioso es el costo del proceso y el medio de evitarlo es el beneficio de justicia gratuita que puede ser total o parcial; o también -de no proceder éste- por su similar efecto, las litis expensas. (Es Obvio que no me refiero a abaratar los servicios de justicia dada su escasez de personal y de medios materiales).

Todo proceso tiene irremediablemente un coste y dentro de él se comprenden las costas procesales. En especial dentro de estas la partida de mayor importe son los honorarios de los abogados. Se añaden los honorarios de peritos, el arancel de los procuradores, las indemnizaciones a testigos por desplazamiento, las tasas judiciales (suprimidas por fortuna no hace mucho), el papel oficial (-suprimido-) que incluía el impuesto de actos jurídicos documentados ...

Para las personas que no tengan derecho al beneficio de justicia gratuita ese gasto supone un límite de acceso al proceso. Mucha gente prefiere no pleitear evitando ese gasto conforme al dicho popular del gitano "pleitos tengas y los ganes". Para los que tengan derecho a ese beneficio de forma limitada, la parte no cubierta es un límite al derecho de acceso. Los que disponen de él en su integridad, es una forma de suprimir o rebajar -en su justa medida- ese límite de acceso a la jurisdicción. Por ley se regulan los supuestos en que procede tal beneficio y su ámbito (garantía legal). El art. $119 \mathrm{CE}$ se refiere a él y su ulterior ley reguladora. Los que carecen de él tienen que sufragar todo y queda claro tal como opera ese límite. 
6) No abordamos los límites extrajurídicos en el acceso a la jurisdicción pero que tienen su vertiente social. Así en el proceso penal mucha gente se piensa mucho si debe o no denunciar un delito o querellarse sea o no víctima de él (Libertad sexual, corrupción, cometidos por bandas armadas y elementos terroristas...), por simple temor a los efectos sociales y jurídicos que puede tener sobre todo si están amenazados. Algo semejante sucede en el ámbito administrativo sobre todo en caso de corrupción. Pero también destaca el miedo o temor a las presiones sociales en el orden civil y laboral.

7) Con carácter general, en todo proceso (civil, laboral, penal, y contencioso administrativo) desde su nacimiento, desde la litispendencia. los actos de comunicación a las partes actora y pasiva, cualquiera que sea la tipología del acto de comunicación y el medio a través del que se hace (personal, correo certificado, internet...), deben hacerse con todas las garantías procesales. Es una consecuencia de la garantía del derecho al proceso debido, del derecho de defensa y la proscripción de la indefensión. (Art. $24 \mathrm{CE}$ ).

Por lo tanto, no debería existir límite alguno a que se haga con todas las garantías esa comunicación, salvo resolución judicial en contrario motivada mientras sea necesario el mantenimiento del secreto. El respeto a las garantías formales de los actos de comunicación afecta a su validez. Puede hablarse de diversas categorías si faltan así: nulidad absoluta, nulidad relativa o invalidez, subsanabilidad o no, validez de los mismos pudiendo ser irregulares o regulares; siempre en relación a la garantía procesal que implica el derecho de defensa.

8) Otro límite previo al inicio del proceso o una vez iniciado son las cauciones procesales que debe soportar el demandante así para la adopción de las medidas cautelares previas o coetáneas (contracautela); o el demandado (caución sustitutiva) para sustituir las medidas adoptadas por éstas. Incluso pueden establecerse, aunque no así en España, para iniciar el proceso en primera instancia y así acceder a la jurisdicción. $\mathrm{O}$ ser de otra especie.

Es común su exigencia para la interposición y admisión de los recursos extraordinarios de infracción procesal, de casación, o en procesos extraordinarios de impugnación como la revisión. (Exigen depositar la cantidad establecida en la cuenta bancaria de la Caja general de Depósitos del Ministerio de Justicia, a los efectos procedentes).

9) Semejante a los referidos y que actúa como un fuerte límite es la exigencia de las tasas judiciales que además en muchos casos exi- 
gen anticipar todo su importe con un depósito en la cuenta bancaria del Ministerio de Justicia para que el procurador pueda comenzar su representación. Idem el papel sellado en que se redactaban los escritos judiciales (demanda, contestación... Hasta 1978 se exigieron. Con la $\mathrm{CE}$, en base al art. $24 \mathrm{CE}$ se suprimieron. Con la crisis económica el gobierno del PP volvió a introducir las tasas judiciales que unos años después fueron suprimidas). Ya me referí a ambos supuestos.

10) Otro límite relativamente frecuente en el Derecho comparado es la exigencia de una cuantía mínima para el acceso al proceso en primera instancia, cuando se trata procesos con un determinado objeto o incluso con carácter general. Se trata de que toda cuantía mínima (procesos de bagatela), es decir, insignificante, queda excluida del acceso al proceso. Pensemos en reclamaciones de cantidad por i6mporte inferior a 50 Euros.

\section{LAS GARANTÍAS AL SERVICIO DE LA JURISDICCIÓN (ART. 117 CE), LO ESTÁN TAMBIÉN AL SERVICIO DEL JUSTICIABLE EN CUANTO FORMAN PARTE TAMBIÉN DEL DERECHO A LA TUTELA JUDICIAL EFECTIVA (ART. 24 CE).}

El artículo $117 \mathrm{CE}$ establece una serie de garantías procesales de la jurisdicción contenciosa (pero también algunas están al servicio de la jurisdicción voluntaria si es judicial). Lo son al servicio de la jurisdicción y objeto de la tutela que todos conocemos, (y que los órganos del Estado deben respetar, prestar y colaborar en su desempeño, art. 118 CE, y bajo tutela del CGPJ o Ministerio de Justicia dentro de sus respectivas competencias). Afectan al órgano jurisdiccional y al "tramitador" procesal o Letrado de la Administración de Justicia.

Pero a su vez estas garantías son un instrumento para que la tutela judicial sea efectiva (art. $24 \mathrm{CE}$ ), pues sin su concurso podría ser inefectiva. En este sentido su cometido está al servicio de los justiciables, al servicio de la propia acción entendida como libre acceso a la jurisdicción y al proceso; y son el instrumento adecuado para el desempeño de la jurisdicción que consiste en juzgar y hacer ejecutar lo juzgado (art.117-3 CE).

Me limitaré a enumerarlas, pues su desarrollo excede del cometido de este trabajo. 
1) La jurisdicción ordinaria forma parte del Poder Judicial y es única al tener como base la unidad jurisdiccional. A Salvo las jurisdicciones especiales que no forman parte de él.

2) La jurisdicción es independiente de los otros poderes del Estado, de entidades públicas o privadas y de los ciudadanos.

3) La inamovilidad de los jueces y magistrados es una garantía jurisdiccional no pudiendo ser cesados, removidos o trasladados más que por las causas previstas en la Ley. (Ver $6^{\circ}$ )

4) Los jueces y magistrados son responsables en el ejercicio de su función jurisdiccional sea esta civil, administrativa e incluso puede ser penal. Esto sin perjuicio de la responsabilidad del Estado, art.121 CE en caso de error judicial o por el funcionamiento anormal de la justicia (así dilaciones indebidas del art. $24 \mathrm{CE}$ ). Y con la garantía de reserva legal en cuanto a los supuestos de responsabilidad y sus requisitos.

5) Sumisión al imperio de la Ley (o normas inferiores) de los jueces y magistrados y en ningún caso a los dictados de sus superiores jerárquicos. Esto sin perjuicio del valor de la doctrina legal del TS (fuente indirecta) y la del TC (fuente directa).

6) No pueden ser separados del cuerpo judicial, ni suspendidos, ni trasladados, ni jubilados salvo por las causas y con las garantías previstas en la Ley. (LOPJ, por tanto, garantía de reserva legal, que además es por Ley Orgánica al referirse a uno de los poderes del Estado). Remito a lo dicho en la independencia en cuanto es consecuencia de ella.

7) La exclusividad de la jurisdicción consiste en juzgar y ejecutar lo juzgado, no pudiendo realizar los jueces y magistrados otras funciones, salvo las que les fueran atribuidas por ley en garantía de cualquier derecho como sucede con la jurisdicción voluntaria, extradición activa o pasiva u otras específicas. (Se evita así que tengan interés directo o indirecto al dictar las resoluciones judiciales que afectan sobre todo al fondo).

8) El Estatuto de los jueces y magistrados de la jurisdicción ordinaria se regula por Ley (reserva legal) que además es Orgánica por regular uno de los poderes del Estado y es la LOPJ. Además, disponen de un órgano administrativo específico, para garantizar su independencia del ejecutivo, evitando su dependencia en gran medida, del Ministerio de Justicia. Es el CGPJ con unas competencias administrativas específicas. 
9) El cometido de la función jurisdiccional, y en salvaguarda de las garantías procesales citadas, exige que estén sometidos a un régimen especial de incompatibilidades que evite su posible interés directo o indirecto al dictar resoluciones judiciales. Art. $127 \mathrm{CE} \mathrm{y}$ LOPJ.

10) La garantía del Derecho al juez ordinario, predeterminado por la Ley (en la jurisdicción ordinaria, art. 24-2 y 117-3 CE; e incluso inserto en una jurisdicción especial como la militar al amparo del art. 24.2 CE), supone una reserva de Ley Orgánica en cuanto referido a la jurisdicción ordinaria. Es la LOPJ y en ella aparece determinada la competencia objetiva y funcional de los jueces y magistrados. Además, reserva de ley procesal ordinaria para las leyes que regulen su respectiva competencia territorial y que en el caso de la LECRIM exige ser orgánica. Por lo tanto, Derecho al juez ordinario predeterminado por la Ley conforme a las normas que determinan la competencia objetiva, territorial y funcional y respecto a esta última en la instancia respectiva de que se trate.

$\mathrm{Y}$ entiendo que igualmente se extiende al que resulte determinado conforme a la aplicación de las normas de régimen interno que regulan y concretan el reparto del órgano individual o la sección respectiva del órgano colegiado en el caso concreto.

Según lo dicho en estos apartados no parece existir gran diferencia entre la jurisdicción contenciosa y la jurisdicción voluntaria de carácter judicial respecto a dichas garantías procesales.

\section{GARANTÍAS RESPECTO A LA UNIDAD Y LAS FORMAS DEL PROCESO Y PROCEDIMIENTO.}

Deben destacarse como garantías procesales:

1) Garantía de legalidad procesal (reserva de ley en todo caso; e incluso de Ley Orgánica en la regulación de las normas procesales que afecten al desarrollo de los derechos fundamentales y libertades públicas, limitándolos. Así de los art. 17, 18, 19, 20, 25 CE y de la legislación orgánica sobre Administración de Justicia y competencia objetiva y funcional conforme al art 81 y 122-1 CE y en cuanto aparece desarrollado en la LOPJ).

2) Garantía de la unidad legal del proceso y del procedimiento para todo el territorio nacional cuando se trate de juzgar y ejecutar lo juzgado conforme a las normas materiales que sean aplicables a todo el territorio nacional. La legislación procesal en tal caso es una 
competencia exclusiva del Estado Art. $149-1-5^{\circ}$ y $6^{\circ}$. Por lo tanto, el marco procesal laboral y penal es único y lo es siempre para todo el Estado. Art. 149-1-6 . El marco procesal civil (orden jurisdiccional civil) es también en todo caso único en el Estado para la aplicación de las normas mercantiles (art. 149-1-6º). También es único el marco procesal para aplicar las normas civiles y administrativas de la competencia exclusiva del Estado (art. 149-1-6 $6^{\circ}$ y $8^{\circ}$ ) y para las extranjeras cuando proceda su aplicación (art. 12 CC y $149-1-6^{\circ}$ y $8^{\circ}$ ). Sería de aplicación a la jurisdicción voluntaria para la efectividad de derechos que resulten de las competencias exclusivas del Estado.

Es discutible si es único o no el marco procesal civil y el administrativo cuando sea para aplicar la normativa material civil o administrativa que sea de competencia exclusiva de las CCAA, aunque deberá preverse en su Estatuto de Autonomía igual que sucede con la competencia de los TSJ de las CCAA para conocer del recurso de casación foral o autonómico. Es reproducible lo afirmado en este párrafo para la jurisdicción voluntaria.

3) Garantía procesal de respetar el proceso y procedimiento predeterminado por la ley, es decir el correspondiente al objeto deducido. Vulnerarlo, en muchos casos conllevará la nulidad de actuaciones si con anterioridad no se subsanó este defecto en la instancia respectiva en que se cometió. Por lo tanto, a esta declaración de nulidad tenderá el recurso de apelación, infracción procesal, nulidad de incidentes o amparo ante el TC. El art. $24 \mathrm{CE}$ habla de un proceso con todas las garantías y el respeto a las formalidades del procedimiento es una garantía para deducir en forma su objeto y para la defensa jurídica apropiada de que se sirven ambas partes.

4) Garantía de la publicidad del proceso. Art. 24-2 y 120 CE. Sin perjuicio de las excepciones que prevean las leyes de procedimiento. La publicidad va ligada al principio de oralidad, inmediación, concentración, a la rapidez del proceso, a la unidad de secuencia en que se realizan actos procesales de distinto carácter, al principio de preclusión flexible de los actos procesales, a la necesidad de reproducir las actuaciones grabándolas o dejando constancia escrita de ellas el Letrado de la Administración de justicia. Se oponen al mismo la publicidad restringida (publicidad sólo para las partes y no para terceros) y el principio de secreto que afecta a terceros, pero incluso podría serlo para las partes pasivas en el sumario, y podría estar proscrito si afecta a su derecho de defensa.

El principio de escritura conlleva a los principios opuestos: mediación, dispersión de los actos procesales, lentitud o dilación, plu- 
ralidad de periodos o fases según el carácter de los actos procesales en cuestión a realizar en la misma instancia, preclusión rígida, es innecesario reproducir las actuaciones por estarlo ya. El principio de escritura fuera del marco penal del juicio oral no supone su inconstitucionalidad, art. 120-2 CE, ni vulnera el art. 24 CE. Pero la oralidad como garantía procesal es un principio programático del proceso y procedimiento predeterminado por la ley para futuras reformas legislativas.

Cuando la oralidad es un requisito "sine qua non" su vulneración supondrá lo dicho en el anterior párrafo. Es además la publicidad una garantía social que a través de los medios de publicidad se conocerá el estado de nuestra Administración de justicia e igualmente sirve de medio para denunciar la corrupción administrativa o judicial con la publicidad de los actos procesales y las sentencias, que serán publicadas, aunque se supriman los nombres y apellidos de las víctimas y se sustituyan por iniciales (correspondan o no a sus nombres y apellidos) si afecta a las sentencias el principio de secreto.

La publicidad para los terceros tiene sentido en un proceso oral, cualquiera que sea su especie, respecto a las audiencias públicas (proceso penal en el juicio oral, no así en el sumario que es predominantemente escrito) o en la comparecencia del proceso civil. Sin embargo, en un proceso escrito se debe tener mucho cuidado con que terceros sin legitimación material puedan examinar los autos pues sería un grave riesgo para que se vulnerasen derechos fundamentales como el derecho al honor, la intimidad y la propia imagen; o para que se menoscaben, alteren o se hagan desaparecer los autos.

Vulnerar la publicidad, puede formar parte del supuesto c, en cuanto suponga la alteración del proceso o del procedimiento predeterminado legalmente.

5) La garantía de oralidad. La recoge el Art.120-2 CE y es consustancial al juicio oral del proceso penal que corresponde a la segunda fase del proceso penal en la primera instancia. En materia laboral y civil se puede decir que el proceso es hoy oral. El proceso civil de la vigente LEC 2000 ha pasado a ser oral, a diferencia con el de la LEC 1881 (vigente hasta el año 2000) que era predominantemente escrito sobre todo el de mayor cuantía.

Si la oralidad es requisito "sine qua non" del proceso y del procedimiento es de aplicación lo dicho en el punto c.

Las consecuencias de la oralidad y escritura son las ya expuestas. Aunque la esencia de la oralidad y la publicidad debe radicar en el 
principio de inmediación del juez con los abogados defensores de las partes (y la de estas en sus actos personalísimos). De faltar dicha inmediación juez, tramitador procesal, letrados, partes de poco o nada sirven la oralidad y la publicidad.

\section{GARANTÍAS DEL PRINCIPIO DE APORTACIÓN SEGÚN RIJA O NO EN EL PROCESO EL PRINCIPIO DISPOSITIVO. RELACIÓN CON LA ACCIÓN, LA FUNDAMENTACIÓN FÁCTICA Y JURÍDICA, LA CAUSA PETENDI Y LA LEGITIMACIÓN. RELACIÓN CON EL DERECHO DE DEFENSA Y LA CONGRUENCIA.}

1) Antes de entrar en el examen de fondo, se nos plantea una duda. Si la acción entendida como acceso a la jurisdicción es previa al proceso y es un derecho de carácter constitucional (Guasp Delgado); es previa al proceso y sirve para excitar la actividad jurisdiccional (Fairén) hasta el fin de este; o por el contrario forma parte del proceso desde el momento inicial, origina su litispendencia y se mantiene hasta el momento final en que la cosa juzgada, manifestación de la jurisdicción (art. $117 \mathrm{CE}$ ) satisface la acción y pretensión (tutela judicial efectiva, art. $24 \mathrm{CE}$ ).

Y si forma parte la acción del proceso desde su inicio si puede iniciarse con total abstracción (teoría abstracta de la acción, que sustenta Almagro en cuanto así se permite el libre acceso a la jurisdicción sin mayor restricción siempre que se cumplan los presupuestos procesales) o se exige cierta concreción en el acto de la pretensión del actor (demanda) mediante su fundamentación fáctica y jurídica (o fundamentar la excepción de fondo del demandado, pero en este caso nunca su derecho de acción procesal puede ser previo al proceso, pues surge ya iniciado tras la presentación y admisión de la demanda con el acto de su contestación). Y si la legitimación procesal (apariencia jurídica del derecho material deducido) es consecuencia de la acción y el medio de concretarla subjetivamente junto con la fundamentación fáctica y jurídica de la pretensión y excepción (objeto). (Teoría concreta de la acción).

A esta segunda concepción (teoría concreta) responde el art. 24 CE y sobre todo la vigente Ley de la Jurisdicción Contencioso Administrativa (obsesionada con la legitimación y la cuestión de fondo desde el inicio del proceso administrativo, tras la interposición del recurso e incluso antes de la demanda contencioso administrativa): pero obsérvese que según el precepto constitucional pasa a ser una 
cuestión de límites que no se determinan y con carácter finalista (art. 24-1CE) para el ejercicio de los derechos e intereses legítimos mediante la pretensión o la excepción, de forma que cuanto más se exija su concreción más se puede limitar e incluso impedir el acceso a la jurisdicción (v. gr. exigiéndose aportar documentos que justifiquen la titularidad del derecho o interés jurídico reclamado es decir la cuestión de fondo en ese momento) y cuanto menos más se facilita.

Algo semejante parece suceder con la vigente LEC 2000 en su exigencia de la fundamentación fáctica y jurídica y que podría suponer un defecto formal en la redacción de la demanda y contestación; y por su carácter subsidiario, art. 4 LEC podría afectar al proceso laboral.

En ambos casos la acción abstracta o la concreta respecto al acceso a la jurisdicción sería una consecuencia de la litispendencia (art. 411 LEC), que se produce con efectos retroactivos desde el momento de la presentación de la demanda si fuera admitida ésta a trámite de concurrir los presupuestos procesales (proceso civil, laboral y contencioso administrativo; o de la querella en el proceso penal). La demanda o la querella sería la forma a través de la que mediante la acción en sentido procesal se accede a la jurisdicción.

Esto es importante pues se siga una $\mathrm{u}$ otra de estas concepciones se llega a resultados, constitucionales muy diferentes, en cuanto a la garantía procesal de la acción y en su caso respecto al proceso de amparo constitucional de denegarse ese acceso.

Por el contrario, si se considera la acción procesal previa al proceso, medio de iniciarlo, para excitar (Fairén) o vincular la actividad jurisdiccional y ligada al derecho político y constitucional (Guasp) sería un medio de acceso abstracto a la jurisdicción y no concreto.

2) El principio de aportación implica que la parte actora es la que debe aportar al proceso a través de la acción, fundamentando la pretensión en la demanda los hechos constitutivos de su pretensión; y el demandado a través de la acción al contestar la demanda los hechos constitutivos de su excepción de fondo que serán los impeditivos, extintivos o excluyentes para desvirtuar la pretensión del actor. Esto es así en el proceso civil, laboral y contencioso administrativo.

3) El juez no puede introducir de oficio los hechos constitutivos de la pretensión del actor en el proceso, aunque los conociera por su conocimiento privado, es decir por medios ajenos a los escritos presentados por las partes o a sus declaraciones y que constan en los 
autos. Lo que no está en los autos no está en el mundo. Igual sucede con los hechos constitutivos de la excepción material de fondo, si bien aquí según el supuesto concreto del tipo de hecho se debe distinguir si deban proceder de los escritos o las declaraciones aportadas por el demandado o también si resultan de los hechos aportados por el actor. Incluso aunque sean notorios no puede el juez hacerlo de oficio, pues se vulneraria el derecho de defensa de las partes y la independencia judicial, aunque estén por su notoriedad exentos de prueba y baste su alegación por las partes.

Sin embargo, en el proceso penal y en el sumario esa aportación puede corresponder al juez instructor por iniciativa propia o porque se lo pida el Ministerio Fiscal o las partes acusadoras e incluso acusadas. En el juicio oral, concluido el sumario por auto firme, parece que los hechos esenciales (acción antijurídica y culpable y el resultado de esta acción delictiva) no se pueden modificar en lo sustancial. Aunque existe la iniciativa probatoria del órgano jurisdiccional de oficio (Art. 729-2 LECRIM) o a instancia de las partes acusadoras (probar los hechos constitutivos del delito, art. 650-4 y 656 LECRIM) y de las acusadas los hechos (art. 650-4 y 656 LECRIM) que lo impiden (causas de justificación), extinguen el delito o su pena (prescripción del delito o de la pena) o excluyen el delito o su pena (excusas absolutorias en el primer caso o las inmunidades personales de jurisdicción, art. 666-1 LECRIM en el segundo).

Lo afirmado en párrafos anteriores es una consecuencia del derecho de defensa y de la proscripción de la indefensión, art. 24-1 y 2 CE.

4) Pero no basta con aportar y alegar los hechos de forma nuda, como sucedieron en la realidad, sino que es conveniente que se califiquen jurídicamente al fundamentarlos (en cuanto puede incidir la teoría de la sustanciación o de la individualización en su determinación (o en lo penal art. 650 en el supuesto del concurso ideal de delitos), y que es una consecuencia del derecho de defensa y así su motivación y fundamentación jurídica es una garantía del derecho de defensa de la parte y de la contraparte y garantía de la motivación y fundamentación de la ulterior sentencia que dicte el órgano jurisdiccional.

La demanda, vehículo de la acción debe estar fundamentada en los hechos y el derecho aplicable y motivada. Debe motivarse la consecuencia jurídica solicitada en la pretensión, o en la excepción de fondo material a través de su fundamentación -fáctica y jurídicamente- por la que se pide la misma. $\mathrm{O}$ en el escrito de calificación ju- 
rídica o de acusación y defensa (650). Y concretar la causa petendi, que de ser varías (en el proceso civil, laboral y contencioso administrativo) deben señalarse todas en el mismo momento al estar sometidas por la vigente LEC 2000 a diferencia con la LEC 1881 al principio de preclusión rígida. En el proceso penal, igualmente, pero en tal caso si hay varias causas y derivan de unos mismos hechos estaríamos ante un concurso ideal de delitos, es decir un concurso de calificaciones jurídicas para unos mismos hechos.

5) Motivación y fundamentación fáctica y jurídica supone subsumir los hechos y la consecuencia jurídica solicitada -en la pretensión o excepción material- en una norma. Y dentro de ella en el presupuesto fáctico y la consecuencia jurídica prevista en la misma. $\mathrm{O}$ en el escrito de calificación jurídica denominado también de acusación y defensa.

6) Y si dentro de esa misma norma (precepto legal) o en otras normas (preceptos legales) se prevén distintos efectos jurídicos respecto a unos mismos hechos (causa petendi) deben solicitarse todos ellos a la vez (especificando el precepto jurídico en que se contienen) y en el mismo momento al no caber otro momento para hacerlo por el principio de preclusión rígida de causas petendi que establece la vigente LEC 2000 (y por analogía a la LPL y LJCA); a diferencia con la LECRIM que sí lo permite al poderse hacer primero en el escrito de calificaciones provisionales o de acusación provisional de la parte actora y de defensa provisional de la pasiva, y después en el escrito de calificaciones definitivas de ambos (o de acusación y defensa definitiva) e incluso en los informes.

Con otras palabras, queda prohibido el goteo de causas petendi en las leyes citadas, salvo en la LECRIM. Todo ello es consecuencia del derecho de defensa, si bien la prohibición del goteo de pretensiones en el mismo o en ulterior proceso supone un límite al derecho de acción, aun considerándose constitucional.

7) La aportación de los hechos constitutivos de la pretensión y la petición del efecto jurídico pretendido por el actor conlleva varios efectos jurídicos de la litispendencia. Así la prohibición de la transformación del objeto del proceso en lo sustancial, art. 412-1 LEC (dígase de la demanda o de la pretensión) y su permisión en lo accidental, art. 412-2 LEC tanto en el proceso civil, laboral y contencioso administrativo (aunque en éste el objeto quedó fijado en la instancia anterior administrativa del procedimiento administrativo cuando se exige la vía previa administrativa). Y todo ello es una garantía para 
el ejercicio del derecho de defensa del demandado (art. 24 CE y 412 LEC).

Lo mismo sucede respecto al demandado que no podrá modificar los hechos esenciales en que funda su excepción material, ni la petición jurídica en que se ampara (art. 412-1 LEC), pero si los accidentales, 412-2 LEC. Es una garantía para el ejercicio del derecho de defensa del actor (art. 24 CE y 412 LEC).

Queda determinado por la litispendencia el procedimiento legal aplicable hasta la sentencia de instancia o hasta la cosa juzgada según se siga el sistema procesal de la irretroactividad flexible o la rígida (Art. 2 CC y 2 LEC). Y queda determinada de igual forma, la jurisdicción del órgano nacional o extranjero, el orden jurisdiccional competente, así como su competencia objetiva, funcional y territorial. Y en su caso el órgano unipersonal específico o la sección del colegiado que conoce del asunto por virtud de reparto de existir más de uno-a en esa demarcación territorial con igual competencia objetiva, funcional y territorial. Art. 24-2 y 117-3 CE y 411 LEC.

Sin embargo, esto no sucede siempre en el proceso penal, pues los hechos en virtud de los cuales se acordó la conclusión del sumario pueden perfilarse o concretarse en el escrito de calificaciones provisionales o definitivas. Siempre que los hechos sustanciales por los que se dictó el auto firme de conclusión (mientras no sea firme se puede impugnar) se mantengan o respeten, pues de lo contrario podría conculcarse el derecho de defensa del acusado en el juicio oral.

8) El ejercicio de la pretensión por el actor en el proceso civil y laboral (hechos sustanciales de la demanda, petición concreta o súplica, y causa petendi que la justifica) determina la legitimación procesal del actor o actores; pero también la del demandado o demandados. Es decir, la parte actora determina su legitimación (prima facie) y además la del demandado. Perpetua la litispendencia la legitimación activa y pasiva que ya no podrá modificarse salvo en los casos expresamente previstos por la ley que además resultan excepcionales (así para integrar un litisconsorcio pasivo necesario). Por tanto, prohibición del cambio subjetivo de partes en el proceso tras la litispendencia (413 LEC) en cuanto es una garantía del derecho de defensa del actor y demandado (art. $24 \mathrm{CE}$ ).

Salvo que la parte pasiva adujese su falta de legitimación como excepción procesal, que de prosperar pone fin al proceso con una resolución que no se pronuncia sobre el fondo. 
En el proceso contencioso administrativo sucede lo mismo cuando las dos partes son dos Administraciones. En otro caso, la legitimación sustentada por el administrado con base en los hechos sustanciales, la petición jurídica y la causa petendi habrá quedado determinada en la instancia anterior que es administrativa (procedimiento administrativo).

En el proceso penal parte, propiamente dicha, es sólo la pasiva. La actora no es parte material si no procesal, sin perjuicio de su derecho de defensa que se manifiesta acusando en el juicio oral o solicitando antes actuaciones el sumario y puede dejar de serlo (renuncia) cuando lo desee en cuyo caso puede continuar ejerciendo la acción el MF cuando proceda o si es delito sujeto a procedibilidad privada termina el proceso penal.

La parte pasiva lo es desde el momento en que se adoptan medidas cautelares contra él (detención, prisión), desde que como investigado (o imputado, procesado si la sospecha es más intensa) se le insta que nombre un abogado y ejercite su derecho de defensa con base a unos hechos delictivos de los que resulta sospechoso de su comisión o desde que él por propia iniciativa acompañado de su abogado desea declarar de forma voluntaria en un proceso penal. Art. 118 LECRIM y 24-2 CE.

Tres garantías procesales de la parte pasiva penal desde que se dirige un proceso penal contra él coexisten. Derecho a la defensa, Derecho a la asistencia letrada (para el ejercicio de su derecho de defensa), a la asistencia de un intérprete (en cuanto está comprendido dentro del ejercicio de su derecho de defensa si no conoce el idioma del país en cuestión). Derecho a ser informado de la acusación formulada contra la parte pasiva, (entendida la acusación no sólo la formulada antes del juicio oral en el escrito de acusación o calificaciones provisionales o en el propio acto del juicio oral en las calificaciones definitivas tras el auto de conclusión del sumario si no en el propio sumario desde que aparece como sospechosa la parte pasiva para que ejercite su derecho de defensa, según el art. 118 LECRIM). Desde ese momento nace su derecho de defensa.

Y además según el art. $24 \mathrm{CE}$, desde ese momento (cuando se le comunica que se sigue un proceso penal contra él por unos hechos en la fase de sumario), incluso siendo "un simple investigado" y sin que se hayan adoptado todavía medidas cautelares contra él ni se haya llegado al juicio oral), nacen para él otras garantías procesales así el derecho a no declarar contra sí mismo, a no confesarse culpable y a la presunción de inocencia. 
Es posible el cambio de parte pasiva durante el sumario. Dictado el auto de conclusión, su responsabilidad se perfilará en las calificaciones provisionales que pueden modificarse por las definitivas. Si durante el juicio oral se comprueba que no participó en los hechos y lo fueron otras personas se produce una crisis procesal que puede justificar la suspensión o interrupción (paralización) de las sesiones del juicio oral.

9) El deber de motivar y fundamentar la pretensión y la excepción que es consecuencia del derecho de defensa conlleva que la sentencia que en su día se dicte tenga que ser congruente con la pretensión y la excepción.

Para determinar si es congruente o incongruente la sentencia, caso de impugnarse la misma por concurrir el vicio de incongruencia, para ser estimado el recurso (es un vicio procesal de la propia sentencia y no del procedimiento en que se dictó y por ello sería nula la sentencia). El art. 24-1 y 2 CE permite como garantía procesal acudir, agotados los recursos ordinarios al proceso de amparo. (Vulnera el derecho a obtener la tutela judicial efectiva pues en este caso sería inefectiva la obtenida; y el derecho a la defensa jurídica que en este caso sería una indefensión jurídica). Debe ser clara y terminante.

Además, el derecho de las partes y del órgano jurisdiccional (en especial del superior jerárquico que conoce del recurso por este motivo) a la motivación de las sentencias, sirve para concretar la congruencia o incongruencia de la sentencia, aunque la falta de motivación dificultará determinar si la sentencia es o no congruente.

Para determinar la congruencia o incongruencia de la sentencia es necesario comparar su fallo con lo solicitado en la súplica de la demanda (pretensión) y de la contestación (respecto a la excepción); comparar la fundamentación fáctica y jurídica de la sentencia con la de la pretensión y la excepción; y la causa o causas petendi estimadas en la sentencia con las que fundan la demanda y la contestación a ella caso de la excepción.

Debe estar la sentencia debidamente motivada en sus antecedentes y fundamentos fácticos y jurídicos y el fallo. Su motivación en todo caso facilitará la determinación o concreción de la congruencia o incongruencia de la sentencia (sea ésta por conceder más de lo solicitado y resistido -exceso-, séalo por defecto si concede menos de lo pedido por una parte y de lo reconocido por la contraparte, por conceder cosa distinta, o por omisión de alguna pretensión o excepción 
o de alguno de los pedimentos que conformen una única pretensión o excepción).

10) Incluso, una sentencia congruente carente de toda motivación fáctica o jurídica es susceptible del recurso de amparo por vulneración del art. 24-1 y 2 CE (derecho a la tutela judicial efectiva y a la defensa jurídica) y 120-3 CE, (derecho a la motivación de las sentencias) en tanto en cuanto impide o dificulta el derecho al recurso de la parte actora o pasiva que sufre el gravamen (diferencia entre lo solicitado y concedido) y por ello de esa forma impide o limita su derecho a la tutela judicial efectiva y el derecho de defensa de la parte legitimada para recurrir. Pero igualmente dificulta la labor jurisdiccional y enjuiciadora del órgano "ad quem" competente para conocer del recurso ordinario o extraordinario de que se trate pues dicho órgano desconoce por falta de motivación la razón de ser estimatoria o desestimatoria del recurso del órgano "ad quo".

El supuesto de los puntos 8 y 9 es una garantía procesal constitucional en función del justiciable, art. $24 \mathrm{CE}$ en cuanto permite el recurso de amparo; como para la propia jurisdicción en este caso el órgano jurisdiccional "ad quem" que conozca del recurso. En tanto en cuanto a través del recurso se ve afectado (limitado e incluso impedido) por la falta de motivación de la sentencia de la instancia anterior su cometido jurisdiccional de juzgar y (en su caso) ejecutar lo juzgado, conforme al art. 117-3 CE.

11) En el proceso penal la congruencia de la sentencia penal con la acusación y defensa recibe el nombre de correlación entre acusación y sentencia. Debe partirse del contenido del auto de conclusión del sumario (ya que concreta los sujetos que forman la parte pasiva y el objeto o hechos sustanciales investigados durante la instrucción y por los que después se califica), de los escritos de acusación y defensa (calificaciones) provisionales o definitivas e incluso los informes. Y comparar todo ello con el contenido de la sentencia.

La sentencia debe respetar los hechos a que se refiere el auto de conclusión del sumario y las personas referidas como parte pasiva. Respetar la calificación jurídica más grave de los escritos de acusación o defensa provisionales o definitivas o las calificaciones provisionales o definitivas de las partes actoras y pasivas (salvo proposición de tesis para aplicar una pena más grave si el delito corresponde a uno de entidad diferente comprendido en otro título diferente de imputación del CP y estemos ante un concurso ideal de delitos por los mismos hechos debería plantear la tesis, pues si el delito está dentro del mismo título de imputación puede condenar por 
una pena superior) y la pena solicitada o consecuencia jurídica pedida por las partes que en principio, fuera de lo dicho en lo que antecede, no le vincula.

Si el juez en la sentencia penal respeta estos aspectos será congruente al respetar la correlación acusación y sentencia. En otro caso sería incongruente por no respetarla (salvo la pena pedida que no le vincula por el principio "iura novit curia" salvo si se debe a un error en la calificación jurídica del delito según lo dicho).

Sobre esta cuestión, de lege ferenda, se han mantenido dos tesis antagónicas: la primera es la que entiende que la congruencia debe referirse a los hechos tal como sucedieron y son objeto de la acusación (históricos o naturales de la acción y el resultado; o de la omisión y su resultado; o de la comisión por omisión), y a la parte pasiva o sujetos acusados. Sin embargo, la pena solicitada y la calificación jurídica de esos hechos debería quedar fuera de la congruencia y del derecho de defensa con base en el principio "iura novit curia" y de ser así no afectaría al derecho de defensa (Viada Puigcerver).

La segunda entiende que el derecho de defensa (art. $24 \mathrm{CE}$ ) no sólo cubre el elemento subjetivo (acusado) y el elemento objetivo o fáctico (hechos de la acción y su resultado en el sentido expuesto), sino también la calificación jurídica más grave de los hechos por la acusación (aunque esto suponga negar la viabilidad o efectividad del principio "iura novit curia" respecto al juez en tanto en cuanto de apartarse el órgano jurisdiccional de esa calificación jurídica (y de no utilizar la tesis, o forzar al MF a modificar su acusación por esos hechos con base a otra calificación jurídica, o si el MF se niega a informarle de la razón de la calificación jurídica en que funda la acusación -733- o la refiera a un título de imputación distinto caso de concurso ideal de delitos) origina indefensión al acusado.

Es la más acorde con el sentido del art. 24 CE o garantía procesal del derecho a la defensa jurídica del acusado. Pero no afecta a este derecho si impone una pena más grave a la solicitada si esos hechos calificados de otra forma están contenidos en el mismo título de imputación. Afecta pues a la correlación entre acusación y sentencia.

Esta segunda tesis tiene su importancia en el proceso de jurado puro, mantenido en la Ley de Jurado, en los delitos de que es competente, en tanto en cuanto los jurados (sistema de jurado puro) deciden sobre la cuestión fáctica y no sobre la jurídica. De seguirse el sistema de escabinado la cuestión sobre la correlación entre acusación y sentencia sería mucho más compleja cuando el mismo hecho es susceptible de distintas calificaciones jurídicas. 


\section{GARANTÍAS DE LA PRUEBA. LA INDEPENDENCIA DEL JUEZ.}

1) $\mathrm{El}$ art. $24 \mathrm{CE}$ reconoce como garantía procesal el derecho de las partes a utilizar los medios de prueba pertinentes para su defensa. Y viene precedido del derecho a un proceso con todas las garantías. Por lo tanto, se hace referencia a dos garantías procesales de la prueba: utilizar los medios de prueba pertinentes para la defensa excluyéndose los innecesarios o impertinentes; y derecho al proceso y procedimiento legal debido al realizarse la prueba con todas las garantías para la defensa (incluidos los actos de comunicación a las partes para la práctica de la prueba, estar presentes durante su práctica, hacer preguntas al practicarse y contradecir su actividad y resultado).

2) Medios de prueba para probar el objeto probatorio (es decir los hechos sustanciales o accidentales aportados al proceso por cada parte respectiva, que además son hechos contradictorios y suelen ser desconocidos por el juez destinatario de la prueba; o la exploración de una persona que también puede ser objeto de prueba e incluso las normas jurídicas si -como excepción- deben ser objeto de prueba, art. 281 LEC).

Los hechos admitidos en cuanto dejan de ser contradictorios no necesitan probarse en el proceso civil dispositivo, laboral o contencioso. Si el objeto es indisponible el reconocimiento de por sí no produce efectos jurídicos. En el primer caso se busca la verdad formal y en el segundo la real. Otra cosa sucede con la persona o norma jurídica objeto de prueba, pues el hecho de que el objeto deje de ser contradictorio no lo excluye.

Respecto a los hechos contradictorios (Art. 281), lo lógico es que la carga probatoria recaiga sobre la parte que los aportó al proceso. Así el actor debe probar los hechos constitutivos de su pretensión y el demandado los hechos impeditivos, extintivos o excluyentes a los de la pretensión del actor al plantear la excepción material o de fondo fundada en tales hechos (art. 217 LEC).

Quedan a salvo de esta distribución de la carga, (también denominada regla de juicio a la hora de dictar y motivar la sentencia, en tanto en cuanto determina los efectos que la parte que asume la carga de la prueba debe soportar en la sentencia del juez en caso de falta de actividad probatoria o falta de un resultado probatorio positivo). Hay distintos supuestos y referidos al proceso civil disponible, sea civil, laboral o contencioso administrativo. 
El primero, cuando se permite, en virtud de una norma, al juez la facultad de la iniciativa probatoria oficial o de oficio. Art 281-282 LEC respecto a dicho objeto de prueba.

El segundo, cuando se permite al juez que se pronuncie sobre la conveniencia de que las partes le propongan otros medios de prueba diferentes a los propuestos; o que el juez determine que sean los mismos medios de prueba propuestos por las partes, pero su objeto recaiga sobre otros hechos para que el resultado probatorio pueda ser positivo sugiriéndoselo así a las partes (principio de sugerencia procesal) dentro de unos poderes materiales de dirección del juez que podrían considerarse excesivos si suponen la quiebra de la independencia del órgano jurisdiccional y en su virtud se limita o restringe el principio de igualdad de armas en la práctica de las pruebas judiciales lo que puede afectar al derecho de defensa de la contraparte que se vería mermado y donde el juez -más que "juez"asume una posición parcial o de parte.

El tercero, cuando la propia norma procesal modifica la carga de la prueba, art. 217 LEC, incluso llegándola a invertir, sobre la base del principio de la dificultad probatoria o sobre la base del principio de proporcionalidad de dicha carga probatoria (art. 217) en tanto en cuanto afecte o pueda afectar al derecho de defensa. Art. $24 \mathrm{CE}$. O se lleva a cabo la inversión o la modificación de la carga en una norma material.

En estos casos no solo estamos ante supuestos en que se modifica la carga de la prueba si no que entramos también en el campo de la prueba de oficio y su valoración (se asemeja en parte a la prueba legal) y por tanto parece que es discutible si la prueba de oficio por el juez de los hechos debe estar -o no- sometida a la libre apreciación de la prueba y en su caso sometida a la apreciación conjunta de la prueba. En tales casos la violación de una norma legal referida a la carga y valoración de la prueba por el juez, que es impuesta por el legislador representante directo de la soberanía popular podría originar indefensión a una parte si al motivar la sentencia (como luego veremos) omite esta cuestión o se aparta de la norma. E incluso podría motivar un conflicto directo entre los poderes del Estado, el legislativo y judicial objeto de un proceso constitucional competencia del Tribunal Constitucional. Al margen del conflicto de intereses entre lo que es la jurisdicción y tutela judicial (art. 117 CE), y la acción y la "efectiva" tutela judicial (art. $24 \mathrm{CE}$ ).

Lo hasta aquí expuesto para la modificación e inversión de la carga de la prueba, es aplicable a la valoración tasada y legal de cier- 
tas pruebas (cuarto supuesto), impuesta por el legislador en la LEC y por su supletoriedad (art. 4 LEC) -al permitir la analogía directaa la LPL y LJCA. Me refiero a la declaración de una parte sobre hechos que le perjudican en el proceso civil disponible; y al documento público y privado en cualquier proceso disponible a salvo de la impugnación legal del documento aportado y que prospere (así falsedad del documento declarado así en un proceso penal).

Queda fuera de la valoración legal de las pruebas, el proceso penal, sometido a la presunción de inocencia y donde las pruebas practicadas y las presunciones judiciales (indicio) se valoran libremente (y ello es consustancial a las garantías procesales del derecho de defensa en lo jurídico penal, del derecho a no declarar contra sí mismo, del derecho a no confesarse culpable y del derecho a la presunción de inocencia, art. $24 \mathrm{CE}$ ).

Además, la presunción de inocencia exige que las pruebas practicadas en el proceso penal produzcan un resultado positivo y suficiente de cargo (prueba de cargo, incluso mediante la prueba del indicio consistente en una presunción judicial) para desvirtuar la presunción de inocencia y así se hará constar al motivar y fundamentar fáctica y jurídicamente los hechos probados (acción y resultado penal y causas de su exclusión) y las personas que los cometieron (antijuridicidad y culpabilidad o causas de exclusión de ellas).

En quinto lugar, cuando en virtud de una presunción legal iuris et de iure se tenga por probado un hecho como acaecido (o no acaecido), pues no admite prueba en contrario de la contraparte (y ello podría originar indefensión a una parte, art. $24 \mathrm{CE}$ ); o se trate de una presunción legal iuris tantum (se presume ese hecho como acaecido, o no, salvo que la contraparte pruebe lo contrario, asumiendo en este caso la carga de la inversión de la prueba es decir probar lo contrario a lo que se presume. Pero la prueba del hecho negativo o no acaecido puede suponer una prueba diabólica que origine indefensión a la contraparte (art. $24 \mathrm{CE}$ ). Obsérvese la importancia del garantismo procesal respecto al derecho de defensa en las pruebas, sobre todo las sujetas a valoración legal, como las presunciones.

Si el ámbito de la carga de la prueba respecto al hecho que es su objeto no es total, si no parcial y esto se permite legal o jurisprudencialmente, estamos en el supuesto de las presunciones judiciales o prueba indiciaria. El resultado probatorio positivo del indicio supone la del hecho presumido (aunque éste no se pruebe), salvo que la contraparte pruebe lo contrario, es decir pese a que se probó el indicio por la parte, la contraria demuestre que el hecho presumido 
por la presunción judicial o indicio no acaeció. Se limita pues el derecho de defensa de la contraparte si quiere evitar la virtualidad de la prueba indiciaria.

En sexto lugar no se olvide que la contraparte tiene la facultad de probar los hechos que conforme a la carga de la prueba corresponden a la otra que los aportó (aunque esto pueda ir contra sus intereses).

Los hechos, además de ser contradictorios deben ser desconocidos para el juez (se supone que los conoce la parte que los aporta o invoca en el proceso, incluso cuando miente si son inexistentes), en tanto en cuanto sucedieron o se produjeron fuera del proceso y el juez es su destinario. Si el destinatario del objeto de la prueba es el juez para lograr su convicción y formada ésta dictar sentencia, parece a primera vista una contradicción (o al menos una tautología) tener que probar hechos que el juez conoce. (Otra cosa son las normas jurídicas, que deben ser objeto de prueba por las partes cuya aplicación reclaman, y que el juez conozca por su conocimiento privado o de otros procesos en que las aplicó).

Sin embargo, la necesaria independencia del juez (art. $117 \mathrm{CE}$ ) frente a las partes, evitar su parcialidad o que se convierta en parte, y el derecho de defensa de las partes debería suponer lo contrario, es decir que, aunque el juez conozca los hechos de forma previa al proceso y fuera de los autos estos deben probarse según la distribución que establece la norma de la carga de la prueba o las que la modifican o invierten.

Incluso cuando se autoriza al juez a practicar de oficio la prueba, esta actividad probatoria suya al menos parece o debe parecer consustancial al derecho de defensa de ambas partes, aunque los conozca privadamente; y por esa actividad oficial evitar que una parte se vea favorecida por ella y la otra perjudicada, cuando el objeto es disponible. $\mathrm{O}$ no disponible, aunque existan intereses superiores para su defensa que justifiquen su prueba de oficio. Incluso en este caso no puede el juez introducir su conocimiento privado sin esa mínima actividad probatoria (principio de mínima actividad probatoria) y qué de practicarla el juez de oficio, impide que introduzca (de oficio) su conocimiento privado en el proceso.

Otra cosa es que ese conocimiento resulte de los autos, pero en dicho caso estamos ante la prueba documental. Ya dijimos, que el juez tampoco puede aportar los hechos al proceso; pero en el supuesto que abordamos ahora estaban aportados, mas no probados y sí el juez los conocía por su conocimiento privado, debe probarlos 
de oficio cuando proceda mediante la prueba por él acordada, y con la participación de las partes en su práctica garantía de su derecho de defensa (art. $24 \mathrm{CE}$ ). Incluso en el caso de los hechos notorios no puede el juez aportarlos de oficio al proceso (salvo si constan en autos) pero sí tenerlos por probados de oficio una vez aportados por las partes, pues lo contrario dejaría sin efecto el derecho a la defensa (art. $24 \mathrm{CE}$ ) de las partes del proceso.

El principio de defensa jurídica justifica que el juez no puede en el proceso, respecto a los hechos aportados, respectivamente por cada parte (el juez en ningún caso puede aportarlos a los autos supliendo esa actividad de las partes que es una carga procesal justificándolo en su conocimiento privado, pues pasaría a ser parte y originaria indefensión a la contraparte) tenerlos por probados con base a su conocimiento privado, salvo los notorios ya aportados, por tanto sin una mínima actividad probatoria instada por la parte interesada y sin la mínima actividad probatoria que deriva de la intervención oficial del juez en la prueba cuando tiene esa facultad jurisdiccional concedida por las normas materiales o las procesales (art. 281-282 LEC).

Pues vulneraria el derecho de defensa de la contraparte e incluso su derecho a la contradicción de la prueba en la fase conclusiva del proceso respecto a la prueba por el juez de oficio practicada y su resultado.

Siempre a salvo de los hechos notorios, pues por su notoriedad puede conocerlos el juez de oficio y tenerlos por acaecidos si estaban ya aportados. O incluso sin estar obligado a conocerlos (v. gr. Si sucedieron en la localidad donde tiene su sede y no se encontraba en la misma cuando sucedieron), en este caso puede ser innecesaria toda actividad probatoria de los mismos; pero si los desconoce, también el juez, al ser el destinatario de la prueba puede exigir a las partes su prueba si no los considerase notorios; o exigir a las partes que los reconozcan como sucedidos; o incluso sin conocerlos puede el juez investigar de oficio su existencia (supliendo la falta de su conocimiento privado) exonerando así a las partes de toda actividad probatoria respecto a los mismos.

De todas formas, la contraparte en el ejercicio de su derecho de defensa puede negar la notoriedad del hecho o el hecho en sí debiendo decidir el juez si es o no notorio, e incluso podría la contraparte negar y probar su falta de notoriedad o incluso probar su inexistencia, cuando se tenían por notorios hechos inexistentes y 
que eran por tanto manifiestamente falsos, pero se tenían por ciertos por la fama o rumor público.

El derecho de defensa en el ámbito del proceso civil, laboral y contencioso administrativo tiene su base en el principio dispositivo y en el ámbito de la prueba se busca la verdad formal (de ahí los efectos de los hechos admitidos, las presunciones legales iuris et de iure o iuris tantum, las presunciones judiciales o que se admitan medios de prueba sujetos a valoración tasada o legal) salvo en supuestos regidos por el principio de indisponibilidad del objeto en que se busca la verdad real con la prueba. El proceso penal busca la verdad real y los hechos reconocidos o admitidos no producen los efectos jurídicos del proceso dispositivo o lo hacen de otra forma sin vincular la convicción del órgano jurisdiccional. A salvo de la conformidad, conforme al principio de oportunidad y en lo que respecta a la pena que es la consecuencia jurídica penal.

Al buscarse la verdad formal en el proceso disponible civil, laboral o contencioso es admisible la valoración legal de la prueba en los supuestos dichos. Junto a otras pruebas que están sometidas a la libre valoración del juez dentro de las máximas de la experiencia o del criterio racional o humano.

La motivación de las sentencias, art. 120 CE conforme a las leyes procesales es fundamental y exige que dentro de dicha motivación se haga una valoración separada de la prueba legal y de la libre respecto a los hechos que se consideran probados y según el designio de la prueba legal o libre. Por supuesto la prueba libre está sometida a las máximas de la experiencia o del criterio racional o humano que limitan la discrecionalidad o arbitrariedad del juez. Además, esa motivación facilitará, en su caso, la motivación del recurso si la parte que sufre gravamen por la sentencia decide recurrirla. Y una mejor comprensión del contenido de la sentencia impugnada por el juez "ad quem" del recurso.

3) La presunción de inocencia, es antagónica con las presunciones legales iuris et de iure o iuris tantum por cuya virtud se presume la comisión de un delito y sobre todo cuando el proceso penal no busca la verdad formal, si no la real; y contraria a las presunciones judiciales salvo cuando el indicio es suficiente y supone una prueba de cargo de que se cometió el delito por alguien y con base en una actividad probatoria que siendo más escasa o simple es suficiente para llevar a un resultado probatorio positivo en la convicción del juez de la comisión del delito y así desvirtúe y deje sin efecto la presunción de inocencia Art. 24-2 CE. Lo mismo debe decirse respecto 
a los hechos penales "notorios" no probados y el conocimiento privado del juez, no admisibles y para los que el art. 729-2 LECRIM admite la prueba de oficio.

La declaración o el reconocimiento de la comisión de hechos delictivos no es suficiente para condenar a una persona de no existir pruebas de cargo en contrario. Pero existiendo sólo sirve de base a los efectos jurídicos de la conformidad si dentro del principio de oportunidad reglada o discrecional es admisible.

En el proceso penal no cabe la prueba legal en cuanto es contraria a la presunción de inocencia y no se busca la verdad formal si no la real. Siempre la prueba está sometida a la libre valoración del juez según las máximas de la experiencia o el criterio racional o humano y estar debidamente motivada en la sentencia, art. $120 \mathrm{CE}$ y 741 y 742 LECRIM y sobre la base de las garantías procesales de la prueba referidas en el art. 24-2 CE.

En el proceso penal, en el sumario, la actividad investigadora acordada de oficio o a instancia de las partes actoras (en especial del MF) o de las pasivas y practicada ante el instructor no tiene propiamente el carácter de prueba y debe ser reproducida para alcanzar ese carácter en el juicio oral salvo el caso de la prueba anticipada practicada en el sumario con todas las garantías legales. Dicha investigación está sometida a los límites que dichas garantías procesales determinan respecto a la defensa de la parte pasiva.

Se habla de actividad investigadora más que probatoria, pues esta se realiza en el juicio oral con todas las garantías salvo el supuesto de la prueba anticipada que deba realizarse durante el sumario si no se puede reproducir en el juicio oral y en tal caso se practicará con las mismas garantías (art. $24 \mathrm{CE}$ ) que en el juicio oral. En el juicio oral puede el juez o tribunal acordar pruebas de oficio Art. 729-2 para probar el objeto del auto de conclusión del sumario y de las calificaciones provisionales o definitivas.

4) La prueba debe practicarse, en todo proceso, a instancia de las partes o del juez, cuando es de oficio y se le permite (art. 281 y 282 LEC); y con todas las garantías que determinan las normas procesales, en el momento oportuno sea o no anticipada, y conforme a los medios de prueba pertinentes para su defensa. Art. 24-2 CE.

Vulnerar las garantías de la prueba durante el procedimiento probatorio, o las garantías que derivan de los actos de comunicación referidos al día de la práctica de la prueba en cuanto garanticen el derecho de contradicción de la prueba durante su práctica, 
del hecho mismo al que se refiere su objeto si no resulta prohibido o si se precisa previa autorización, la adecuación y proporcionalidad del medio de prueba utilizado, o que el fin pretendido con la prueba no esté permitido puede suponer la nulidad de la prueba practicada en cuanto pueda incluirse dentro de la categoría de la prueba prohibida.

O si el juez deniega indebidamente el objeto de prueba o los medios de prueba pretendidos que tiendan a ese fin. Entra en juego entonces la cuestión de la denegación del medio de prueba solicitado, el objeto al que se refiere, la valoración del resultado probatorio obtenido indebidamente, incluso el ámbito al que puede alcanzar la valoración de la prueba prohibida practicada (es decir, si es total o parcial). Son pues garantías procesales referidas a la práctica y valoración de la prueba.

No son iguales por tanto los efectos de la prueba en el proceso civil, laboral y administrativo, que en el penal. Así la prueba penal practicada sin las garantías procesales o prohibida, puede afectar al principio constitucional de la presunción de inocencia o al principio "in dubio pro reo" a la hora de dictarse la sentencia penal de primera instancia o en caso de impugnarse después, por este motivo, a la sentencia de la segunda instancia o a la de casación.

De todas formas, la valoración de la prueba legal o libre y su posible vulneración (si fuera irracional) en el proceso de objeto disponible y fuera del ámbito de la necesaria motivación de la sentencia puede determinar la efectiva o inefectiva tutela judicial y afectar al propio derecho de defensa y permitir en su caso el recurso de amparo. Garantía procesal constitucionalizada. La apreciación conjunta de la prueba no debe ser la excusa que ponga límite al derecho de defensa de las partes.

5) La prueba debe ajustarse a las garantías procesales para que pueda considerarse adecuada, válida, y lícita. Es adecuada cuando el medio de prueba resulta apropiado para probar su objeto. En otro caso no tendría un resultado probatorio positivo. Válida si se practica según lo previsto en la ley y comunicándose a las partes el lugar, día y hora de su práctica para asegurar el principio contradictorio y su posterior valoración por las partes. Lícita por su fin y formalidades. La prueba en otro caso puede ser inadecuada, irregular, inválida, ilícita o prohibida si su objeto no se adecua a la misma, a sus formalidades y garantías procesales y sus efectos dependerán de su posible subsanación o no; o del ámbito de su infracción. 


\section{GARANTÍAS PROCESALES EN LA CONCLUSIÓN DEL PROCESO.}

Se tratan de garantías de carácter instrumental a la prueba practicada -o a la no practicada- por causas ajenas a las partes e incluso ajenas a la acordada por el órgano jurisdiccional cuando éste tenga la facultad de acordarlas de oficio y pese a ello no se pudieron practicar. Son una manifestación del derecho de defensa de las partes en lo que se refiere a la prueba practicada e incluso no practicada por causas ajenas a las partes o al propio órgano jurisdiccional o tramitador procesal. Trata de evitarse que por dicha causa se pueda originar indefensión a una o ambas partes respecto a la prueba oportuna de su pretensión o de su excepción.

1) La conclusión puede ser oral o escrita. Consiste en un resumen de la prueba practicada por la parte y la contraparte y del resultado positivo o negativo alcanzado y el valor concedido (en la práctica quien la propuso da una valoración positiva a la suya practicada y negativa a la practicada por la contraria). Así se prevé en el proceso civil, laboral y el contencioso. Su razón de ser se refiere a la prueba practicada en el proceso en la fase probatoria propuesta a instancia de cualquiera de las partes o la oficial del juez. No tiene sentido si no se practicó prueba en esta fase del juicio.

Es discutible si la conclusión debe servir para valorar la prueba documental aportada por cada parte con la demanda o contestación de la demanda, aunque lo lógico es que al inicio de la comparecencia se hubiera discutido sobre el particular. Sin embargo, si se impugnó como falso el documento aportado por la contraparte y se inicia un proceso penal a esos efectos podría valorarse en la conclusión.

2) En el proceso penal, el equivalente a la conclusión son los informes que hacen los abogados de las partes, referidos en los art. 735 y 738 LECRIM. Incluso puede tener ese fin conclusivo la última palabra del acusado, art. 739, si justifica su presunción de inocencia, previo el asesoramiento legal del letrado encargado de su defensa.

3) Como señalé al inicio de este epígrafe, en el proceso civil y por extensión el laboral y contencioso administrativo, es posible que si la prueba, admitida como procedente por el órgano jurisdiccional, no se pudo practicar por causas ajenas a las partes puedan éstas solicitar al juez (e incluso en casos muy excepcionales de oficio el órgano jurisdiccional) que acuerde diligencias finales. Incluso la acordada por el juez de oficio, si no pudo practicarse. Se Justifica en el 
derecho a la defensa jurídica de las partes por la prueba. A diferencia con las diligencias para mejor proveer del antiguo art. 340 LEC (su ámbito se amplió en la reforma urgente de la LEC -de 1881-, en 1984) y su objeto era ampliar el plazo (así el dicho popular "diligencias para mejor retardar") del juez para dictar sentencia y así acordadas considerar su conducta diligente y que no fuera objeto de reproche alguno.

En el proceso penal no existen diligencias finales. Su fin se sustituye con la suspensión del juicio oral (o su simple interrupción si es posible) por motivos tasados. Art. 744 y ss. LECRIM y el poder oficial en la dirección de la prueba por el órgano jurisdiccional (si es colegiado, su presidente) o acordando pruebas de oficio el Juez o Tribunal. 683 y $729-2$.

\section{GARANTÍAS PROCESALES DE LA SENTENCIA.}

Remito a lo dicho en la prueba sobre su motivación en la sentencia a que se refiere la CE art. 120. Al orden con que se debe exponerse el resultado de la prueba a que se refieren los preceptos de la LOPJ, la LEC y la LECRIM. La motivación exige claridad y precisión en el lenguaje jurídico. Remito también a lo expuesto en el principio dispositivo, respecto a la congruencia de las sentencias civiles, laborales y contencioso administrativas.

Motivación y congruencia subjetiva de la sentencia respecto a las partes que actuaron en el proceso. Objetiva respecto a los hechos alegados por ellas al fundamentar la pretensión y la excepción y sí resultaron o no probados según la regla de juicio y la valoración de cada prueba practicada (a ser posible de forma individualizada y no en su conjunto); respecto a la causa o causas petendi si son varias las invocadas por parte del demandante o del demandado y que incide sobre la fundamentación jurídica de la pretensión, excepción y sentencia; y la petición concreta o súplica de la pretensión (demanda), de la excepción material (contestación de la demanda) y el fallo criterios, pues, con los que se determina la congruencia o incongruencia de la sentencia.

Incluso en el proceso indisponible la congruencia debe guardar relación con lo que fue objeto del proceso que incumbe introducir al MF y las partes. Incluso de permitirse "alguna" aportación al juez, algo extraño en un proceso que no sea penal (en este cabe en el sumario, por el instructor) y que excede con mucho a que el juez pueda acordar la prueba de oficio sobre lo ya aportado por las par- 
tes, art. 282 LEC, la sentencia para respetar el derecho de defensa y la congruencia debería incidir en este particular.

Una sentencia carente de toda motivación o que sea totalmente ilógica, irrazonada, carente de toda fundamentación fáctica y jurídica, o sin fallo, sin perjuicio de su nulidad vulnera el art $24 \mathrm{CE}$ es decir el derecho que todos tienen a la tutela judicial efectiva y que es la razón de ser del art. $117 \mathrm{CE}$, de la jurisdicción y función de juzgar al caso concreto.

En el proceso penal ya me referí a la motivación y a la correlación entre acusación, defensa y sentencia. (Es decir a las partes pasivas objeto de la acusación penal y en qué concepto lo son; hechos penales -acción, omisión y resultado- aportados y probados por la acusación y por la defensa; calificación jurídica de los hechos por la acusación y la defensa -así los hechos impeditivos, extintivos o excluyentes del delito o la pena-; y la pena solicitada por la acusación y defensa).

No entramos por la extensión del trabajo en la motivación y congruencia en las sentencias de mera declaración, constitutivas o de condena del proceso civil, laboral y contencioso administrativo. Tampoco en la sentencia penal condenatoria o absolutoria. Ni en el motivo específico que debe invocarse para justificar el recurso de casación o el de infracción procesal en los órdenes civil, laboral, penal y contencioso administrativo.

\section{GARANTÍAS PROCESALES DE LOS RECURSOS. ACCESO A LOS MISMOS. PERMISIÓN O PROHIBICIÓN DE LA "REFORMATIO IN PEIUS".}

Una garantía procesal de suma importancia es el derecho de acceso a los recursos. A través de ellos se consagra la protección legal y jurisdiccional de estas garantías que es una consecuencia del derecho a los recursos. No estamos ante un juego de palabras para decir lo mismo, si no ante dos cosas diferentes (una es material, otra formal). A la vez del derecho a los recursos surgen otros efectos y consecuencias que son garantías procesales.

1) La garantía procesal del derecho a la doble instancia. En el orden jurisdiccional civil, laboral, penal y contencioso administrativo está reconocido con carácter general el derecho a la segunda instancia, es decir (en sentido estricto) el derecho a recurrir las sentencias (o resoluciones que ponen fin a la instancia pronunciándose sobre 
el fondo) siempre que al recurrente le originen un gravamen material (diferencia entre lo solicitado en su pretensión o en su excepción material y lo realmente concedido en la sentencia). Es presupuesto de la segunda instancia la existencia de un gravamen material, pues si una sentencia concede lo pedido no existe gravamen y es irrecurrible como principio general.

En el ámbito penal se considera, la doble instancia, un derecho fundamental y una garantía procesal según la declaración del Convenio Europeo de Derechos humanos y el TEDH.

La segunda instancia se lleva a cabo a través del recurso de apelación y como recurso que es no supone una reproducción de la primera instancia, pero admite -en su caso- actividad probatoria respecto a los hechos nuevos o desconocidos que no fueron objeto de prueba, ni podían serlo, en la primera instancia por ser nuevos o desconocidos en el momento en que podían aportarse al proceso.

Sin embargo, existen supuestos de personas aforadas (orden civil, contencioso y penal) o que sin ser aforadas participan en un delito con aforados, o si se trata de un delito conexo (para no dividir la continencia de la causa) en que conoce el Tribunal Supremo en primera instancia y contra su sentencia no cabe recurso alguno por tanto ni la apelación ordinaria ni el recurso de casación extraordinario. (V.gr. al ser notoria la sentencia del "proçés").

En este caso la justificación se funda en que conoció de la primera instancia el órgano superior que ostenta el vértice de la pirámide de la jurisdicción ordinaria: el TS y ser colegiado al integrarlo varios magistrados. No es óbice afirmar que en este caso no está reconocido en nuestro derecho positivo el derecho a la doble instancia en el orden penal que sí reconoce el CEDH y el TEDH, al no admitirse como parece lógico un recurso de apelación ( $\dot{i} . . . ?)$ contra una sentencia del TS y ante el mismo TS. Pero tampoco existe el recurso de casación ante el propio TS si éste dictó la sentencia de instancia. (Debería admitirse el recurso de casación con cierta amplitud, al ser más limitado que la apelación, contra la sentencia del TS, en este caso ante una Sala especial del TS que actuará en Pleno y de la que no formarán parte los magistrados que lo fueron en la primera instancia).

En este caso no prevé nuestro proceso penal el derecho a la doble instancia y por tanto no existe la garantía procesal penal de la doble instancia penal, ni la del derecho al recurso contra toda sentencia penal (la casación es más restrictiva que la apelación). Existen muchas SS. del TEDH. que critican duramente la falta de esta garantía 
en el ámbito penal. No parece que la justificación orgánica (el TS es el vértice de la jurisdicción ordinaria) de quién dictó la sentencia en este caso, art. $123 \mathrm{CE}$, sea suficiente para impedir que no exista la garantía procesal del derecho a la doble instancia penal o al recurso penal tal como proclama el art.10-2 CE que remite al CEDH y a la jurisprudencia del TEDH.

También en el orden jurisdiccional penal se criticó que la LECRIM originaria admitiera la apelación para el juicio de faltas (hoy desaparecido tras su despenalización) y no cupiera el de apelación para los delitos y sí el de casación en su caso. Reformas posteriores de la LECRIM admitieron el recurso de apelación para los delitos menos graves (así desde 1967 en que se creó el proceso de "urgencia" por la ley reguladora de las infracciones penales derivadas del uso y circulación de vehículos de motor; la reforma de 1980 respecto a delitos graves, menos graves y flagrantes...; la del proceso penal abreviado en sus diversas variantes; y la del proceso penal de jurado con un ámbito limitado) y sin embargo para los delitos graves no cabía el recurso de apelación si no el de casación. (Casación algo más amplia que la del proceso civil para adecuarla al derecho de defensa consagrado en el art. $24 \mathrm{CE}$ ).

Pues bien, la última reforma de la LECRIM, en 2015, admite con carácter general la doble instancia penal admitiendo sin cortapisas el recurso de apelación en el proceso por delitos graves. Y además se amplía el ámbito del recurso de casación siguiendo las líneas del TEDH conforme al Convenio Europeo Derechos Humanos para su defensa dotándolo de garantías públicas procesales Art. $10 \mathrm{CE}$. Esto a priori es positivo. Sin embargo, la crítica a la reforma de 2015, por los procesalistas, no es porqué se establezca la doble instancia penal y el derecho al recurso contra la sentencia penal si no por el régimen procedimental establecido para estos recursos y la posible sobrecarga de trabajo en los TSJCCA en su Sala Penal. Llevan razón en muchas de sus críticas. También es cierto, como dice el dicho popular, "que no siempre es oro todo lo que reluce".

2) Este derecho a la doble instancia en el orden civil, laboral y contencioso administrativo se reconoció desde las leyes originales de enjuiciamiento (LEC 1855, 1881 y 2000; LPL 1995; y LJCA de 1956 y 1998)). Hoy sin embargo en lo civil, empieza a ser cuestionado. Si debe seguirse manteniendo para cuantías mínimas o por el contrario debe suprimirse o limitarse. De suprimirse se acabaría con esta garantía procesal en procesos de poca importancia o cuantía económica. Otros proponen que en estos casos se limite el acceso al recurso exigiendo que recaiga sobre ciertas materias (para unas sí y 
otras no y limitarse en cuantías pequeñas), o qué se restrinja exigiendo cauciones altas para poder recurrir que serían desproporcionadas respecto a la cuantía del recurso... De ser así se impediría o limitaría el acceso al mismo.

Este derecho a la doble instancia es una garantía procesal para evitar la injusticia de una sentencia sujeta a errores de forma o de fondo al aplicar inadecuadamente el derecho procesal o material al caso concreto.

3) El derecho a la doble instancia (apelación) no supone sin más el derecho de acceso a los recursos extraordinarios como son el de infracción procesal y casación en el ámbito civil, laboral y contencioso administrativo. El acceso a éstos, su supresión o restricción es compatible con esta garantía. En los órdenes jurisdiccionales civil y contencioso administrativo existen los recursos extraordinarios, aunque se ha limitado su acceso hasta extremos incomprensibles e insospechados.

Se exigen cuantías desmesuradas como caución, para poder interponer los recursos extraordinarios en el orden civil (sobre todo en los que son competencia del TS) y laboral; hay que justificar previamente el depósito de la caución en todos los órdenes jurisdiccionales para que se tenga por preparado e interpuesto; no existe un recurso de casación especial (o un motivo dentro de éste) en el orden civil cuyo objeto sea la defensa de la legalidad y doctrina legal del TS aunque sólo estuviera legitimado para ello el MF y aunque no se modifique la sentencia de apelación que es firme desde que se dicta y al sólo efecto de crear doctrina legal del TS.

Se admite en el orden civil en algunas materias cierta amplitud en su permisibilidad (así en caso de vulneración de los derechos fundamentales de los art. 14 y ss. CE, admitiéndose aunque la cuantía económica sea baja); y si el objeto del recurso no se funda en su vulneración es casi imposible o muy restrictivo por la cuantía económica exigida para poder recurrir de $600.000 €$; incluso en algunas materias específicas ni siquiera se admite aunque la misma exceda de $600.000 €$ de impugnarse sentencias dictadas en apelación de procesos plenarios especiales o tramitados por el juicio verbal.

En el ámbito contencioso administrativo cada vez es más restrictivo el recurso de casación, aunque haya desaparecido el requisito excesivamente formalista de tener que fundamentarse para poder recurrirse en casación el "juicio de relevancia" respecto a la sentencia dictada en apelación y la futura que se dicte en casación. 
Mucho de lo afirmado para el recurso de casación, es reproducible para el recurso extraordinario de infracción procesal, en el orden civil (si el derecho privado aplicado es el común general y no el autonómico o foral pues conocería entonces el TSJCCAA), pues conoce del mismo el TS y no los TSJCA como preveía la LEC 2000, en su redacción originaria y cuyo marco legal esta suspendido. Pues según los Acuerdos del TS -que determinan el régimen de aplicación modificado (de los artículos originarios de la LEC que están suspendidos de aplicación, más no derogados al carecer el TS de esta competencia)-, se exigen requisitos comunes muy semejantes -para el recurso de infracción procesal seguido ante el TS dado su carácter restrictivo- a los de la casación, para la interposición de dicho recurso.

Sólo se ha ampliado el ámbito al recurso de casación en el orden penal, con lo que el acceso al mismo tiene una mayor dimensión y conlleva una ampliación de esa garantía procesal. Tras el recurso de apelación penal cumple pues un fin material (justicia material frente a la violación material de la norma penal) y procesal (justicia formal ante violaciones de las garantías procesales).

4) Los recursos son el medio de protección de las garantías procesales pues a través de ellos se canalizan e instrumentan; de forma que a medida que los requisitos exigidos para prepararlos o interponerlos sean menores, mayor será el ámbito y la facilidad de protección y viceversa. Pero el recurso no es el único medio para su protección.

Estamos en supuestos de vicios procesales (inexistencia si bien con cierta apariencia de existencia, nulidad absoluta, o relativa versus anulabilidad, irregularidad, e incluso respecto a actos válidos y regulares) que limiten, cercenan o impiden las garantías procesales. Incluso, dichas garantías procesales pueden afectar a los presupuestos procesales (óbices procesales) o a las condiciones de procedibilidad (óbices de procedibilidad) o al propio derecho de defensa (art. $24 \mathrm{CE}$ ). Cuanto antes se subsanen estos vicios mejor para la viabilidad adecuada del proceso.

e) Como recursos, en el orden civil, para la protección de las garantías procesales merecen citarse el de reposición (providencias, autos, diligencias de ordenación) siempre en la misma instancia en que se produjeron. De ahí que no sea un recurso devolutivo y se denomine por otros, remedio.

El de apelación devolutivo ante el superior, contra autos y sentencias, por vicios cometidos en la primera instancia anterior, donde se denunció el vicio tras su comisión. Es el medio más efectivo para 
dejar sin efecto los vicios, (inexistencia con apariencia de acto, nulidad absoluta o relativa), y que se proceda a su subsanación repitiéndolo de nuevo o no (v.gr. si el vicio se cometió en la propia sentencia recurrida) en una nueva primera instancia desde que se cometieron y haciendo así efectivas las garantías procesales vulneradas.

El recurso extraordinario de infracción procesal contra sentencias cuando el vicio se cometió en primera o segunda instancia, siempre que se denunciara en su momento y sin perjuicio del recurso de reposición en la instancia respectiva.

En los otros órdenes jurisdiccionales (laboral, penal y contencioso) existen recursos semejantes reciban esa denominación u otra diferente. V.gr casación por defectos de forma. Además, está el incidente extraordinario de nulidad de actuaciones cuando no se puedan interponer los recursos antes vistos.

Firme la sentencia cabe el proceso de amparo ante el TC, con base en cualquiera de los motivos previstos en el art. $24 \mathrm{CE}$ y en la LOTC reguladora del recurso de amparo. Y tras esta sentencia (que es constitutiva y vincula a todos los poderes del Estado) se puede acudir al TEDH siempre que esa garantía procesal sea reconducible a los supuestos en que produzca indefensión.

Cuando una resolución judicial o una sentencia no sea clara, precisa, o no esté suficientemente motivada (art. 24 dentro del derecho a la tutela judicial efectiva y 120 CE, 218 LEC y concordantes LOPJ), contenga errores materiales a instancia de parte o del MF, o incluso de oficio (art. 214 LEC) puede pedirse o llevarse a cabo su aclaración y corrección. O subsanarse, de igual forma, art. 215 LEC.

5) El principio de contradicción y de congruencia en los recursos y la garantía procesal de la prohibición de la "reformatio in peius" o su admisibilidad tienen consecuencias. Cuando una sentencia es impugnada por una parte porque la misma le origina un gravamen material (e incluso procesal) tiene legitimación para recurrirla. El recurso puede ser ordinario o extraordinario (apelación o casación) y referirse al orden civil, laboral, penal o contencioso administrativo.

Pues bien, si la contraparte (actor o demandado; apelante o apelado del recurso) no la recurre de forma independiente, o no se adhiere al recurso del recurrente, esto supone para el recurrente una garantía procesal y que es una consecuencia del principio de contradicción que el órgano jurisdiccional no podrá dictar una sentencia más gravosa que la de la instancia impugnada, aunque fuese procedente. Por el contrario, si la contraparte recurre de forma indepen- 
diente o se adhiere al recurso del recurrente podrá ser más gravosa, perjudicial, suponerle más gravamen que la dictada en la instancia anterior, siempre que proceda según la norma material.

Si se tratara de un recurso de apelación penal, siendo esto cierto, el órgano penal que conozca del recurso de apelación (o casación) deberá respetar además la necesaria correlación entre acusación, defensa y sentencia penal de la primera instancia desde el plano de la tipificación subjetiva y objetiva y la calificación jurídica más grave objeto de acusación si no se planteó en la primera instancia en el acto de juicio oral la tesis respecto a un título de imputación diverso y en otro título del código penal del que fue objeto del mismo.

V.gr. En primera instancia se calificó el delito como tráfico de drogas y estupefacientes, por la acusación y defensa y por este se condenó en la sentencia de primera instancia; no podrá el recurrente en segunda instancia aducir que existe un concurso ideal de delitos para que sea condenado además de por ese delito por el que lo fue, por el delito de contrabando (concurso ideal de delitos al ser los mismos hechos) imponiéndosele además por ello una pena superior. Ello es así porque en nuestro sistema el derecho de defensa penal (art. $24 \mathrm{CE}$ ) no supone necesariamente una "cuestio facti" por los mismos hechos, si no que puede suponer además una "cuestio iuris" de entidad suficiente para desvirtuar el derecho de defensa en los supuestos de concurso ideal de delitos que implique un concurso de normas o preceptos penales.

6) El derecho a los recursos lo es dentro del ámbito permitido por las leyes procesales para las garantías procesales. Así la apelación puede permitir, sin ser una nueva instancia (no es una reproducción de la primera), una actividad probatoria respecto a los hechos nuevos o desconocidos que no fueron objeto de la primera. Sin embargo, la casación por su esencia no lo permite. (A salvo que el legislador, pretendiera bajo el techo y la forma de la casación crear un recurso híbrido de apelación y casación).

\section{LA GARANTÍA PROCESAL DE LA COSA JUZGADA.}

Mediante ella se hace efectivo, en sede jurisdiccional (como reza de su nombre y es la manifestación exclusiva y genuina de la jurisdicción; aunque existen institutos equivalentes cuyos efectos jurídicos se asimilan, pero su origen no está en la jurisdicción si no en el acuerdo común de las partes materiales como sucede con la transacción, la conciliación, el arbitraje, la mediación procesal o extra- 
procesal o los acuerdos procesales...) el valor común a todo ordenamiento jurídico cual es la certeza y seguridad jurídica (art. 1, 9-3 $\mathrm{CE}$ ). Sólo en ocasiones el valor justicia en detrimento de la certeza y seguridad jurídica puede justificar la revisión de una sentencia firme, si fuera considerada por el legislador como injusta con base en unos motivos concurrentes cuando se dicta.

El art. 117-3 CE se refiere a ella, de forma implícita, como una manifestación de la potestad jurisdiccional con la expresión juzgando (presuponiendo que es definitiva e irrevocable la sentencia). $\mathrm{El}$ art. $118 \mathrm{CE}$, explícitamente a la firmeza, "Es obligado cumplir las sentencias y demás resoluciones (de fondo, por tanto; no lo son las que no se pronuncian sobre el fondo en caso de incumplimiento de los presupuestos procesales) firmes de los jueces y tribunales. Y en el art. $24 \mathrm{CE}$, implícitamente, en la expresión tutela efectiva, lo que supone que una tutela judicial que no es firme no puede ser efectiva en su plenitud en tanto en cuanto puede ser revocada; de ahí el art. 118 CE referida a la misma. Igualmente, los art. 222 LEC y 666-2 LECRIM abordan la cosa juzgada.

Se justifica como una garantía procesal, que la cosa juzgada formal impida que puedan acceder al curso de un proceso de declaración finalizado nuevas actuaciones procesales (salvo las referidas a la ejecución si la pretensión era declarativa de condena). Y que las referidas a la pieza de ejecución procesal, firme la sentencia y concluida la ejecución procesal (cosa ejecutada según Carnelutti) se tengan por concluidas sin poderse añadir nuevas actuaciones a dichos autos. (Efecto interno).

Y como efecto externo que no se puede iniciar un nuevo proceso idéntico al ya finalizado por sentencia firme entre las mismas partes y con el mismo objeto (efecto negativo o non bis in idem). Y si así fuera que se pueda de oficio o a instancia de parte (excepción de cosa juzgada) dejar sin efecto el segundo proceso (y sus correspondientes actuaciones) en el curso en que se hallen. $\mathrm{O}$ incluso, qué si el segundo proceso terminó por sentencia firme, que ésta sea nula en todo caso (ya en lo que contradiga a la primera en cuanto discordante; como en lo que confirme a la primera por ser entonces inútil e innecesaria).

Y además como efecto positivo, que si se inicia un nuevo proceso entre las mismas partes pero con distinto objeto, si el segundo objeto fuera prejudicial del primero que la sentencia del segundo proceso tenga que respetar la del primero en todo lo que la condiciona, vincula, prejuzga o le es prejudicial. 
La cosa juzgada es una consecuencia de la jurisdicción contenciosa, pero no sólo de ella. También lo es del proceso contradictorio y del principio de contradicción. En los equivalentes jurisdiccionales ese efecto llamado "cosa juzgada" no es tal. Si no la consecuencia de tal equivalente, el acuerdo común de las partes, en el que no interviene la jurisdicción como tal si no un tercero que es un árbitro o las propias partes (conciliación, arbitraje, mediación, transacción, acuerdos procesales). Las garantías en estos casos no son procesales o jurisdiccionales, si no materiales en cuanto derivan del acuerdo de las partes para resolver sus diferencias o para acudir al arbitraje, sin perjuicio que se proscriba la indefensión (art. $24 \mathrm{CE}$ ) o que el consentimiento que da origen a tales figuras esté viciado (1811 y ss. CC. y su equivalente en la LJV para la conciliación).

Cuando no existe contradicción (es decir dos partes enfrentadas), sino una que reclama la constitución de un efecto jurídico o sólo su declaración como en la jurisdicción voluntaria (donde no se puede solicitar una petición de condena frente a nadie que no es parte, donde sólo existe una parte, y cuando se pide algo frente a alguien sólo cabe el proceso) carece de sentido hablar de cosa juzgada material. Y en cuanto a la cosa juzgada formal supone el cierre de ese procedimiento y de sus actuaciones.

Es pues una garantía, en este sentido, que una resolución dictada en sede de jurisdicción voluntaria no pueda afectar a quienes no fueron parte para evitar su indefensión, art. $24 \mathrm{CE}$. Interesados son los que coadyuvan a ese interés con los solicitantes del acto de jurisdicción voluntaria; o se oponen -pero sin hacer contencioso el expediente- para que la resolución que se dicte no sea estimatoria del acto en sí solicitado.

\section{LAS GARANTÍAS PROCESALES DE LA EJECUCIÓN.}

Dispone el art. $118 \mathrm{CE}$ que "es obligado cumplir las sentencias y demás resoluciones firmes de los jueces y tribunales, así como prestar la colaboración requerida por estos... en la ejecución de lo resuelto".

Igualmente tiene su justificación en el art. $24 \mathrm{CE}$, pues la tutela judicial efectiva para serlo requiere la ejecución propia o específica de las sentencias que son declarativas de condena (así en el orden civil, laboral, penal y contencioso administrativo) es decir condenen a una prestación. Sea al pago de una cantidad de dinero, a la entrega de cosas sean genéricas o específicas, a un hacer o a un no hacer 
sean ambos genéricos o específicos. Incluso las constitutivas pueden exigir la ejecución "impropia" consistente en la inscripción del contenido de la sentencia en registros públicos para preservar el valor de certeza y seguridad jurídica común a todo ordenamiento jurídico.

Quedan fuera de la ejecución las sentencias meramente declarativas porque agotan en sí mismas el objeto de la tutela judicial efectiva haciendo innecesaria toda ejecución voluntaria o forzosa.

La ejecución voluntaria o forzosa exige para ser efectiva la correlación entre la sentencia firme que la acuerda y el auto o autos en que se concreta y materializa la ejecución. Por lo tanto, la congruencia de la sentencia debe ser puesta en relación con el auto que acuerda la ejecución. En otro caso se vulneraria esta garantía procesal y ante su incumplimiento proceden los recursos ordinarios o extraordinarios respectivos. La claridad, precisión, concreción, fundamentación y motivación de las sentencias; su aclaración, concreción para salvar algún error (Art. 215 y 218 LEC) es fundamental sobre todo cuando el órgano que tiene que ejecutar la sentencia no es el que la dictó en primera instancia. (Así cuando se dictó la sentencia firme objeto de ejecución en apelación o casación).

Pero además el derecho a la tutela judicial efectiva exige que la ejecución se lleve a cabo en los propios términos establecidos en la sentencia firme que la acuerda (ejecución común) o en los de la sentencia todavía no firme cuando se trata de la ejecución provisional o que es anticipada en el tiempo. Esta última puede exigir cautelas para evitar los efectos de que la sentencia pendiente de recurso fuera revocada o modificada en su contenido por la ulterior firme.

En sus propios términos quiere decir que sólo en casos límites la ejecución específica o propia pueda sustituirse por una ejecución dineraria (a los daños y perjuicios irrogados) cuando la condena a dar una cosa específica (por tanto que no pertenezca a un género incluso aunque fuese un género específico; V.gr. condena a entregar $100 \mathrm{Kg}$ de lentejas del tipo X como semilla de siembra Z) no pueda sustituirse por otra (v.gr. un cuadro determinado de un concreto pintor), o se trate de un hacer personal específico (v.gr. una escultura por un determinado escultor) no sustituible por otro o de condena a un no hacer específico.

Pero incluso en estos casos deben optarse por la imposición de multas coercitivas al obligado a la ejecución específica para que se pueda llevar en sus propios términos y no se tenga que optar por la condena sustitutiva. Esta coacción psicológica, la colaboración con los jueces, en suma, la "coertio" o la coacción de la jurisdicción en el 
proceso de ejecución debería estar al servicio de la ejecución específica tanto en el proceso civil, laboral o contencioso y en este último sobre todo cuando la Administración sea la parte condenada al cumplimiento específico.

\section{LA GARANTÍA DEL DERECHO DE DEFENSA EN LAS MEDIDAS CAUTELARES, EN JUICIOS SUMARIOS Y EN LOS PLENARIOS RÁPIDOS.}

1) El proceso y el respeto a las garantías procesales necesita de un tiempo determinado para que se pueda dictar una sentencia de fondo justa. Pero, ese tiempo imprescindible y necesario que necesita el proceso para que se dicte una sentencia justa ("periculum in mora" o urgencia específica) puede ser utilizado por la parte demandada para hacer inefectiva la sentencia que en su día se dicte con actos específicos propios mientras se tramita; o aprovecharse de la urgencia específica del proceso, dilatando su curso. Son pues instrumentales a esa sentencia, responden a una finalidad de aseguramiento y son temporales pues duran hasta que se dicte la sentencia salvo que se disponga otra cosa.

A ese fin responden las medidas cautelares. Resolver pronto en favor del demandante para solventar ese peligro o urgencia específica y hacerlo siempre que el actor demuestre la probabilidad de que es titular del derecho reclamado en el proceso ("fumus boni iuris") y además si presta una caución (contracautela) que asegure al demandado los daños y perjuicios que la adopción de esas medidas le puede causar. Una vez acordadas estas medidas cautelares y antes de su adopción puede el demandado prestar cauciones sustitutivas para evitarlas. O si ya fueron adoptadas prestarlas para que se alcen.

Deben adoptarse, estas medidas cautelares o la caución sustitutiva, bajo el principio de contradicción procesal tanto si son previas o coetáneas al inicio del proceso. Y ser proporcional la medida adoptada con el peligro que trata de evitar al actor, el daño posible que su adopción puede originar al demandado, la contracautela que presta el actor y el fumus o derecho hipotético del actor. Garantías procesales para actor y demandado que aseguran los riesgos de la adopción de la medida y el peligro de su no adopción; poder sustituir el demandado la medida cautelar adoptada por otra menos gravosa igual de efectiva o segura.

Las medidas cautelares aseguran por tanto el contenido de la sentencia declarativa de condena civil, laboral o contenciosa admi- 
nistrativa (e incluso de la constitutiva si la anticipa en el tiempo, mediante la técnica de la anticipación) que se dicte y a su vez que su ejecución sea posible en sus propios términos. O la sentencia penal que se pronuncia sobre la acción civil derivada del delito que se tiene por ejercitada por el MF en el proceso penal, salvo reserva o renuncia del perjudicado.

En el proceso penal, las medidas cautelares personales están sujetas al principio de legalidad, art. $25 \mathrm{CE}$, al principio de proporcionalidad, art. $25 \mathrm{CE}$, al fin a que tienden conforme a las máximas garantías procesales que establecen los art. 17 y 25 de la CE y que complementa la LECRIM. (libertad provisional, detención, prisión provisional). Se añade el habeas corpus, art. 17-2 CE y su L.O. para evitar detenciones que pudieran resultar ilegales. Se añaden las garantías procesales de las medidas restrictivas de derechos que suelen ser consecuencia de su adopción y a las que se refieren los art. 18, $19,20-3,4$ y $5,22,23,24,28 \mathrm{CE}$

2) En los procesos sumarios -la contradicción está limitada o no se permite en ciertas parcelas (en el ejercicio de la pretensión, de la excepción material de fondo, todos o algún medios de prueba admisibles para probarlas)-, existe la garantía de que no se produce la cosa juzgada; o la cosa juzgada se limita a un ámbito y no se produce en todo lo que está excluido del principio de contradicción permitido a la pretensión o excepción material de fondo o dentro de los medios de prueba admisibles para probarla. Por ello se permite acudir después al juicio plenario sin límite en el ejercicio del derecho de defensa (art. $24 \mathrm{CE}$ ), en el contradictorio (pretensión y excepción material de fondo) y con todos los medios de prueba admisibles para probarlo y poder así salvar el límite impuesto por la sumariedad del contradictorio que le es consustancial por razones de urgencia específica.

3) El proceso plenario rápido es aquél en que se acortan los trámites procesales y los plazos para llevarlos a cabo, pero en ellos no se limita el derecho de contradicción (de la pretensión y de la excepción de fondo) ni el derecho de defensa respecto a las partes, ni se limitan los medios de prueba para demostrar el derecho material de fondo. Produce los efectos propios de la cosa juzgada. Esa reducción de trámites y plazos no debe impedir el derecho de contradicción y de defensa de las partes (art. $24 \mathrm{CE}$ ). Lo contrario podría conllevar la indefensión que prohíbe la CE. Exige proporcionalidad entre esa reducción de trámites y plazos y el derecho de defensa para que la tutela judicial sea realmente efectiva. Art. $24 \mathrm{CE}$. 


\section{LA GARANTÍA PROCESAL DE LA RESPONSABILIDAD JUDICIAL POR DILACIONES INDEBIDAS Y ERRORES JUDICIALES.}

Hemos visto que las medidas cautelares son un remedio a la necesaria tardanza del proceso ("periculum in mora") o a su urgencia específica (en este caso mediante la técnica de la anticipación). Y en este sentido a toda dilación debida o indebida. Dilación debida que se justifica en que el transcurso temporal de los actos procesales es algo necesario para realizar los trámites previstos por la ley en todo proceso, incluso los imprevistos y aquellos de los que no sean responsables el órgano jurisdiccional, sus colaboradores o la Administración de Justicia, si no las partes. Ya me referí a la responsabilidad judicial sea gubernativa, civil o incluso penal Art. 117-3 CE y concordantes LOPJ.

Dilaciones indebidas son las debidas al funcionamiento anormal de la Administración de justicia y de ahí que el Estado asuma su responsabilidad directa por ellas. (Art. 24 CE y 121). No deben ser imputables a la parte perjudicada por ellas, o a su contraparte. La dilación indebida puede ser consecuencia del retraso de un proceso específico desde su inicio a fin; o que se produzca en una instancia (primera, segunda o casación); o por la realización de determinados actos específicos. Y siempre que esto sea imputable a la Administración de Justicia y no al justiciable por su mal (si es general y común) o anormal (en casos específicos) funcionamiento (y siempre por una relación causa efecto).

Lo mismo debe decirse del error judicial, sobre todo en el ámbito penal, donde existe una copiosa jurisprudencia reconociéndolo a personas que fueron encarceladas con ocasión de una medida cautelar que acuerda su prisión provisional o por sentencia firme de condena y que luego se descubre que lo fueron por un error judicial tras ser comprobada su inocencia. Pero la CE (art. 121) y la LO que la desarrolla no limita su ámbito sólo al proceso penal. Cabe la indemnización por ellos en otros órdenes jurisdiccionales (civil, laboral y contencioso administrativo) de existir el error judicial.

\section{LA SALVAGUARDA DE LAS GARANTÍAS PROCESALES A TRAVÉS DE LOS PROCESOS ESPECIALES DE IMPUGNACIÓN.}

Existen procesos especiales, extraordinarios de impugnación, en los que bajo la denominación y apariencia formal de "recursos" su 
objeto se funda en diversos motivos a través de los que se deduce una nueva pretensión autónoma y diferente de la que se dedujo en el proceso cuya sentencia firme es objeto de impugnación. De ahí su denominación.

Estos motivos, que fundamentan fáctica o jurídicamente la pretensión impugnativa, tienen su base en la vulneración, en ocasiones, de algunas garantías procesales a las que nos hemos referido en este trabajo. En tal caso, el valor justicia debe sobreponerse al valor certeza y seguridad jurídica que la cosa juzgada formal y material proporciona en cuanto efecto de la sentencia firme. Se trata de impugnar la cosa juzgada; e impugnada la misma de ser nula la sentencia así obtenida (si lo fue por fraude procesal o provocando la indefensión de una parte, art. $24 \mathrm{CE}$ ) debe repetirse de nuevo el proceso, para que éste se realice respetando íntegramente dichas garantías procesales y se obtenga una sentencia firme no viciada procesalmente y que no origine indefensión.

Así sucede en el proceso de audiencia al rebelde, cuando el demandado no tuvo conocimiento del proceso seguido contra él por imposibilidad de serle comunicado o defectos en esta (por ejemplo, hecha en otro domicilio) lo que le origina indefensión.

También, en el proceso de revisión cuando la sentencia se obtuvo mediante actos de prueba que suponen fraude procesal. Así en virtud de documentos presentados que luego fueron declarados falsos, declaraciones de testigos después condenados por delito de falso testimonio, dictámenes de peritos falsos (el documento que lo contiene) o que declararon en falso (así su declaración al ratificar el dictamen o aclararlo y concretarlo) o falsa pericia. Se añaden otros supuestos de fraude procesal (prevaricación del juez en la sentencia). Afectan pues estos casos a las garantías procesales y en su virtud por vulnerarlas deviene nula la sentencia de fondo firme en que se funda.

O en el proceso de amparo constitucional respecto a garantías procesales fundadas en vulneraciones del art. $24 \mathrm{CE}$. A diferencia con el proceso de amparo para la defensa de otros derechos fundamentales de los art. 14 y ss. que se refiere al fondo (y que permiten antes ser tratados como motivo de un recurso de casación, -no sujeto a la cuantía establecida para el proceso civil de $600000 €$ - y por tanto con mayor amplitud defensiva).

Y finalmente en el proceso de amparo internacional ante el Tribunal Europeo de Derechos Humanos, con base en el Convenio Europeo de Derechos Humanos por violación de las garantías procesa- 
les que reconoce dicho Convenio (o por violar los derechos humanos de contenido material si se refiere al fondo).

\section{EL PRINCIPIO DE OPORTUNIDAD FRENTE AL GARANTISMO PROCESAL.}

A lo largo de este trabajo me referí a las garantías procesales. También me referí a sus limitaciones y a su exclusión. Defendí su virtualidad y su máxima extensión o amplitud como medio instrumental para obtener la tutela judicial efectiva dentro del preceptivo derecho de defensa. Están al servicio de ambas partes procesales y no de una. Al servicio de todas las personas, de todo ser humano por el hecho de serlo, en tanto en cuanto necesita demandar, o sea demandado. Su respeto supone un coste económico, mayor o menor para el erario público. Siempre según se mire $\dot{i}$...? y que todos pagamos con los impuestos. No las podemos, en ningún caso, minusvalorar y mucho menos despreciar.

Frente al garantismo ha surgido un movimiento procesal que sobre la base de la defensa del principio de oportunidad trata de impedir el nacimiento del proceso o ponerle fin anticipadamente por medios extraordinarios sobre la base del consenso o acuerdo logrado entre las partes al margen de él (extraprocesal) o dentro de él (intraprocesal).

Esta forma de pensar, de sentir, de manifestación, muy respetable como todas, me produce cierta congoja, pesar, tristeza... pues implica que no merece la pena luchar por la existencia del proceso, por sus garantías procesales para mejorarlas o acentuarlas, por la defensa de la propia jurisdicción contenciosa en su justa medida, en suma, por nuestra disciplina el Derecho Procesal.

Es cierto que el coste del proceso, su duración, en ocasiones su ineficacia, la escasez de jueces y magistrados, la politización de la justicia, la judicialización de la política, reformas procesales recientes quizá poco afortunadas... pueden poner en peligro todas esas garantías procesales logradas, muchas de ellas todavía muy recientes y que nos fueron concedidas por la vigente CE, en 1978.

Hay que ser optimistas, tener esperanza, ilusión; los inconvenientes señalados no justifican que se tire la toalla renunciando a la acción procesal, a la jurisdicción y al propio proceso, sustituyendo ese "trípode desvencijado" por los medios alternativos al proceso, donde estas garantías son menores, mínimas o brillan por su ausencia y 
por tanto esos medios alternativos lo serían en perjuicio de quienes a ellos se acojan.

\section{CONCLUSIÓN.}

La relación de garantías procesales hasta aquí expuestas viene referida a las que consideramos más importantes. Ni es exhaustiva su lista ni pretendió serlo, pues este trabajo sería muy extenso. El estudio de estas garantías procesales es una consecuencia del garantismo procesal que siempre me inculcó mi Maestro José Almagro. Forman parte de lo que era el objeto de "su Escuela Garantista".

Para terminar, quiero pedir disculpas al amable y paciente lector interesado por las garantías procesales, pues soy consciente que a través de esta exposición no podía alcanzar el grado de precisión y de maestría de mi "Maestro" José Almagro. No lo pretendí pues era consciente desde un principio que era inalcanzable o insuperable, al menos a quien este trabajo escribe.

El objeto de este trabajo era respetar y recordar su memoria con este homenaje, y hacerlo recordando "sus" garantías procesales. Y sobre todo incentivar a los estudiosos del Derecho procesal recordando a José Almagro Nosete, para que se animen, persistan y sepan valorar el garantismo procesal, es decir el valor de las garantías procesales. Pues no es sólo importante, si no es vital para la existencia, el desarrollo, la actualización y la continuidad de nuestro Derecho Procesal. 